\title{
Yerel Yönetimler İçin Karbon Ayak İzinin Belirlenmesi: Ümraniye Belediyesi Örneği
}

\section{B. Hande Gürsoy Haksevenler ${ }^{1 *} \oplus$, G. Nur Çelik Onat ${ }^{1} \oplus$, Begüm Akpinar ${ }^{2} \oplus$, Tuğba Bedel ${ }^{3} \odot$}

${ }^{1}$ Marmara Üniversitesi, Siyasal Bilgiler Fakültesi, Siyaset Bilimi ve Kamu Yönetimi Bölümü, 34820, Istanbul. ${ }^{2}$ Mimar Sinan Güzel Sanatlar Üniversitesi, Mimarlık Fakültesi, Şehir ve Bölge Planlama Bölümü, 34427, İstanbul.

${ }^{3}$ Gaziantep Üniversitesi İktisadi ve Ídari Bilimler Fakültesi, Siyaset Bilimi ve Kamu Yönetimi Bölümü, 27310, Gaziantep.

\section{Özet}

Bugün olumsuz etkileri ile karşı karşıya olduğumuz küresel ısınmanın azaltılması yönünde uluslararası, ulusal, bölgesel ve yerel düzeyde önlemler alınmast yoluna gidilmektedir. Küresel ısınmanın büyük ölçüde kentleşmeden ve kentlerden kaynaklanması, yerel yönetimlere önemli sorumluluklar yüklemektedir. Bu çalışmada İstanbul'un ilçelerinden hızlı bir şekilde gelişmekte olan ve önemli bir nüfusu barındıran Ümraniye ilçesi pilot bölge olarak seçilmiştir. İlçe sınırlart içerisinde yer alan konutlar, sanayiler, ticarethaneler ve resmi kurumlar (hastane, okul, vb.) ile ulaşım kaynaklı karbon ayak izinin belirlenmesinin yanı sira Ümraniye Belediyesinin kendi faaliyetlerinden kaynaklanan karbon ayak izi de belirlenmiştir. Bu kapsamda ilgili kurumlardan toplanan 2017 yll doğalgaz ve elektrik tüketim verileri ile toplu taşıma ve özel araçların güzergah, sayl, yakıt cinsi ve tüketimleri dikkate alınmıştır. Elde edilen sonuçlardan, karbon ayak izinin bu kaynaklar arasında konutlarda \%43, ticarethane ve resmi kurumlarda \%35, ulaşımda \%16, sanayide \%4 ve diş ortam aydınlatmalarında \%1 olarak dağıldı̆̆ gözlenmistir. Bu kaynaklardan özellikle ticarethaneler ve resmi kurumlar (\%29) ile konutlarda (\%22) elektrik kullanımının etkisinin büyük olduğu belirlenmiștir. Ulașımda özel araç kullanımının etkisinin (\%50), toplu taşımaya (\%12) göre oldukça yüksek olduğu tespit edilmiştir. Belediyenin kendi faaliyetlerinden kaynaklanan karbon ayak izinin ise toplam içinde \%3 oranla düşük bir paya sahip olduğu belirlenmiştir. Illçede kişi baına düşen emisyon 2,55 ton CO2/kişi olarak hesaplanmıştır.

Anahtar Sözcükler

Karbon Ayak İzi, Belediye, Konut, Ticarethane ve Resmi Kurum, Sanayi, Ulaşım

\section{Determination of Carbon Footprint for Local Administrations: A Case Study for Ümraniye Municipality}

\begin{abstract}
Since the World is facing with detrimental effects of the global warming, some precautions are needed to be taken at international, national, regional and local levels. The fact that global warming originates mostly from urbanization and cities imposes serious responsibilities for local governments. In this study, Ümraniye which is a rapidly developing and populous district was chosen as the pilot area. The carbon footprint of transportation, housing, industry, public institutions (hospitals, schools, etc.) within the district was investigated. Also the carbon footprint of Ümraniye Municipality's own activities was calculated. In this context, the data of natural gas and electricity consumption as well as the route, number, fuel type and consumption of public transport and private vehicles, collected from related institutions for 2017 were taken into consideration. According to the obtained results, the carbon footprint in the district came from housing, business and public institutions, transportation, industry at the rate of 43\%, 35\%, 16\%, 4\% respectively. Among all, it was determined that especially the effect of the electricity consumption in business and public institutions (29\%) and housing (22\%) were major for the carbon footprint. It was found that the impact of private vehicle use (50\%) was quite high compared to public transport (12\%). The carbon footprint resulting from the municipality's own activities has a low share of 3\% in total. The carbon footprint per person in the district was calculated as 2.55 tonne $\mathrm{CO}_{2} /$ capita.
\end{abstract}

$\underline{\text { Keywords }}$

Carbon Footprint, Municipality, Housing, Business and Public Institutions, Industry, Transportation

\footnotetext{
* Sorumlu Yazar: Tel: +90 (216) 7774266 Faks: +90 (0216) 3089932

E-posta: hande.gursoy@marmara.edu.tr (Gürsoy Haksevenler H), gamze.nur@marmara.edu.tr (Çelik Onat G.N), begumakpinar2102@gmail.com (Akpınar B), bedeltugba27@gmail.com (Bedel T)
}

Gönderim Tarihi / Received : 28/10/2019 


\section{Giriş}

Günümüzde fosil yakıtlarının tüketimi başta olmak üzere endüstriyel faaliyetler, kentleşme, arazi kullanımı ve ormansızlaşma ile atmosferdeki sera gazlarının miktarı artmaktadır (IPCC 2014). Karbondioksit $\left.\left(\mathrm{CO}_{2}\right), \mathrm{metan}_{(\mathrm{CH}}\right)$, diazot monoksit $\left(\mathrm{N}_{2} \mathrm{O}\right)$ ve birtakım florlu (kloro floro karbonlar, CFCs; hidro kloro floro karbonlar, HCFCs; hidro floro karbonlar, HFCs gibi) gazlar olarak tanımlanan (EPA 2019) sera gazları, hem doğal hem de insan kaynaklı olup atmosferdeki, kızıl ötesi radyasyonu emen ve tekrar yayan gaz oluşumlarıdır (UN 1992).

Atmosferdeki sera gazlarının hızlı artışı beraberinde küresel iklim değişikliğini getirmiştir. 1992'de kabul edilen Birleşmiş Milletler İklim Değişikliği Çerçeve Sözleşmesi'nin (BMİDÇS) ilk maddesinde iklim değişikliği; "karşılaştırılabilir zaman dilimlerinde gözlenen doğal iklim değişikliğine ek olarak, doğrudan veya dolaylı olarak küresel atmosferin bileşimini bozan insan faaliyetleri sonucunda iklimde oluşan bir değişiklik" olarak tanımlanmaktadır (UN 1992). Hükümetlerarası İklim Değişikliği Paneli’nin (IPCC) 2018 raporuna göre; küresel sıcaklık ortalaması, endüstrileşme öncesi döneme kıyasla $0,8-1,2^{\circ} \mathrm{C}$ artmıştır. $2030^{\prime}$ lardan itibaren bu artışın $1,5^{\circ} \mathrm{C}$ üzerine çıkması beklenmektedir (IPCC 2018). Hiçbir önlem alınmaması durumunda sıcaklık artışının $2^{\circ} \mathrm{C}$ ve üzerine çıkarak, kuraklaşma, sel felaketleri, salgın hastalıklar gibi endişe verici noktalara gelinmesi söz konusudur (IPCC 2018).

BMIDÇS, insan faaliyetlerinin iklim üzerindeki zararlı etkisini önlemek için sera gazı salımlarının kontrol altına alınmasını hedeflemektedir (UN 1992). Bu kapsamda taraf devletler, iklim değişikliğini önlemek veya bunun zararlı etkilerini en aza indirmek için gereken önlemleri almakla yükümlü tutulmuştur (UN 1992). Sözleşme'de, “ortak fakat farklılaştırılmış sorumluluk” yaklaşımı öngörülmüştür (UN 1992). Buna göre, iklim değişikliğiyle mücadelede, gelişmiş ülkelerin, gelişmekte olan ülkelere öncülük etmesi ve onlarla işbirliği yapması gerekmektedir. Bunun yanında, gelişmiş ülkelerin sera gazı salımını azaltma yükümlülükleri, diğer ülkelere göre daha sıkıdır (ÇSB 2019a). Türkiye, BMİDÇS'nin birinci ekindeki gelişmiş ülkeler sınıfında yer almaktadır (UN 1992). BMIDÇS, 2003'te iç hukukta yürürlüğe girmiştir (URL-1 2003). Bu itibarla, küresel 1sınmaya neden olan sera gazı salımlarının azaltılması ve kontrol altında tutulması, Türkiye'nin de öncelikli hedefleri arasındadır.

BMIDÇS'ye Yönelik Kyoto Protokolü, 1997'de kabul edilmiş ve birinci ekte yer alan ülkeler için somut azaltım hedefleri belirlemiştir (ÇŞB 2019b). Protokol, Türkiye'de 2009'da yürürlüğe girmiştir (URL-2 2009). Protokol'ün kabul edildiği tarihte, Türkiye henüz buna taraf olmadığı için, 2008-2012 arasındaki dönemde, Türkiye'nin somut bir azaltım yükümlülüğünden bahsedilememiştir. 2013-2020 arasındaki dönem için devletlerin yükümlülüklerini belirleyen Doha Değişikliği, 2012'de kabul edilmiştir. Bu değişiklikte de Türkiye'nin herhangi bir yükümlülüğüne yer verilmemiştir (UN 2012).

2020'den sonraki dönem için devletlerin yükümlülükleri, 2015'te kabul edilen Paris Anlaşması ile belirlenmiştir (UN 2015). Türkiye, 2016'da Paris Anlaşması'nı imzalamış ancak henüz onaylamamıştır (UN 2019). Paris Anlaşması; BMIDÇS ve Kyoto Protokolü'nden daha farklı bir konumda yer almaktadır. Kyoto Protokolü'nde bütün devletler için bağlayıcı azaltım yükümlülüklerine yer verilirken; Paris Anlaşması'nda, tarafların kendi yükümlülüklerini kendileri ilan ederek, buna uymaları öngörülmektedir. Bunlar "Ulusal Katkı Niyet Beyanı” olarak anlandırılmakta ve bunların beş yılda bir yenilenmesi gerekmektedir (UN 2015). BMIDÇS ve Kyoto Protokolü, birinci ekte yer alan ülkeler ile ikinci ekte yer alan ülkeleri ayırmıştır. Paris Anlaşması ise sadece gelişmiş ve gelişmekte olan ülke ayrımına yer vermis ve bu ayrımın nasıl yapılacağını belirtmemiştir (MFA 2019).

Türkiye, Paris Anlaşması kapsamında ulusal katkı niyet beyanını sunmuştur. 2021-2030 arası için geçerli olacak bu beyana göre, Türkiye, sera gazı salımlarını \%21 oranında azaltmayı taahhüt etmiştir. Bu oran, artıştan azalım oranı olarak belirtilmiştir. Buna göre Türkiye'nin hedefi, normal şartlar altında 2030'a kadar salınması beklenen sera gazı miktarını \%21 oranında düşürmektir (URL-3 2015). Türkiye, bu hedefi gerçekleştirmek üzere; enerji, sanayi, ulaşım, binalar ve kentsel dönüşüm, tarım, atık ve ormancılık alanında plan ve politikalar belirlemiştir (URL-3 2015).

Paris Anlaşması'nın, bu çalışma açısından asıl önemi, devletlerin yanında, diğer yönetim birimlerini de paydaş olarak tanıyarak sürece dahil etmesidir (UN 2015). Küresel 1sınmanın büyük ölçüde kentleşme ve kentlerden kaynaklanması, yerel yönetimlerin de bu hususta sorumlu olduğunun kabulünü gerektirmiştir (Rosenzweig vd. 2011; URL-4 2018). Bir diğer ifadeyle sadece ulusal düzeyde tedbirler alınması yeterli görülmemiştir. Daha hızlı ve etkili sonuçlar alınması noktasında yerel yönetimlerin, iklim değişikliğiyle mücadelede yerini alması gerekmektedir. Paris Anlaşması öncesinde de yerel yönetimler farklı örgütlerde bir araya gelerek çalışmalara başlamıştır. Ancak uluslararası bir belgede bu durumun ifade edilmesi, henüz harekete geçmeyen yerel yönetimler açısından hem zorlayıcı hem de teşvik edici olacağı için önemlidir.

Yerel yönetimler, merkezi yönetimlere göre kent içindeki faaliyetlere daha yakından tanıklık ve müdahale edebilmekte, dolayısıyla bu süreç içinde önemli aktörler olarak karşımıza çıkmaktadır. Yerel yönetimlerin, iklim değişikliğine karşı önlemler almak için farklı çatılar ve isimler altında bir araya geldiği görülmektedir. Bu çalışmada esas alınan Uluslararası Yerel Yönetimler Sera Gazı Salımlarının Analizi Protokolü (IEAP)'nü yayınlayan Sürdürülebilir Kentler Birliği (ICLEI) ve Türkiye'de bazı belediyelerin tarafı olduğu Belediye Başkanları Sözleşmesi (BBS, Covenant of Mayors-CoM) bu kapsamdadır. CoM, 2008'de kurulduğunda kentlerin AB'nin iklim ve enerjiye ilişkin hedeflerine ulaşmak amacıyla gönüllü olarak bir araya geldiği bölgesel bir inisiyatif konumunda olmuştur. 2008 'de yapılan 21. Taraflar Konferansı'nda (CoP) Sözleşme tüm dünyadaki kentlere açılmıştır. CoM günümüzde iklim değişikliğiyle mücadele eden en büyük yerel işbirliğidir. 
BBS’ye taraf olan belediyelerin ilk olarak yönetiminden sorumlu oldukları alanlarda çıkan ve küresel 1sınmaya neden olan gazları ve bunların miktarlarını tespit etmeleri gerekmektedir. Literatürde bu çalışma "karbon ayak izinin hesaplanması" veya "sera gazı envanterinin çıkarılması" olarak adlandırılmaktadır. Bu çalışmanın da konusunu oluşturan "karbon ayak izi" kavramı sera gazlarının atmosferde hızla birikimine sebep olan insan faaliyetlerinin doğada kalıcı etkilerini tanımlamaktadır. Bir diğer ifadeyle, kişilerin veya kurumların elektrik tüketimi, 1sınma ve ulaşım gibi faaliyetleri sonucu oluşan sera gazı emisyonlarının birim karbondioksit cinsinden ölçümüdür. BBS'ye taraf olan belediyelerin sorumlu oldukları ikinci aşamada ise bir "eylem planı" oluşturulması gerekmektedir. Bu plan kapsamında yerel yönetimler bir "azaltım hedefi" koymalı, azaltım için alınacak önlemleri belirlemelidir. Türkiye'de yer alan 16 belediye de Sözleşme'ye taraftır ve bu çerçevede azaltım ve uyum planı hazırlama yükümlülükleri bulunmaktadır. Ülkemizde Ocak 2020 tarihi itibariyle Antalya Büyükşehir, Bayındır, Bağcılar, Bornova, Bursa Büyükșehir, Gaziantep Büyükşehir, Tepebaşı, Kadıköy, Karşıyaka, Maltepe, Nilüfer, Pendik, Seferihisar, Çankaya, İzmir Büyükşehir ve Şişli, Sakarya, Bolu ve Çorlu Belediyeleri BBS'ye taraf olarak, sera gazı envanterlerini ve eylem planlarını ortaya koymuştur (URL-5 2019). İstanbul, Kocaeli ve Tekirdağ gibi diğer bazı belediyelerin de iklim değişikliği eylem planı hazırlamakta oldukları tespit edilmiştir. Belediyelerin kendi çalışmalarının dışında karbon ayak izinin belirlenmesine ilişsin literatürde de benzer çalışmalar yer almaktadır. Örnek olmak üzere Sözleşmeye henüz taraf olmayan Erzurum ili için (Eren ve Erik 2015), Konya'da Selçuk ilçesi için (Argun vd. 2019), Bursa'da Osmangazi ilçesi için (Turan ve Karaer 2019) karbon ayak izi hesaplanmıştır.

Mevcut çalışmada kentleşme profili, nüfus yoğunluğu, sanayileşme durumu dikkate alınarak Ümraniye Belediyesi’nin karbon ayak izinin hesaplanması amaçlanmıştır. Ümraniye ilçesinin içinde yer aldığı İstanbul ili ve ilçeleri için yapılan literatürdeki çalışmalar gözden geçirildiğinde, İstanbul geneli için karayolu ile ulaşımın (\%23) ön plana çıktığı gözlenirken; Pendik Belediyesi için ilçe sınırları içinde yer alan havalimanın kirletici etkisinin büyük olduğu (Pendik Belediyesi 2015) görülmektedir. İstanbul'un bir diğer ilçesi olan Kadıköy içinse özel ve ticari araçlardaki yakıt kullanımı (\%32) ile konutlarda doğalgaz kullanımın (\%31) olumsuz etkisinin önemli olduğu gözlenmiştir (Kadıköy Belediyesi 2014). Elde edilen sonuçlardan ilçede oluşan sera gazı miktarının değişebilmesinin yanı sıra ilçelerin kendi içlerindeki baskın kirletici faaliyetler de değişebildiği görülmektedir.

Ümraniye Belediyesi, CoM'a taraf olan belediyeler arasında henüz yer almamaktadır. Ancak Türkiye'nin Paris Anlaşmasını imzalaması, yerel yönetimlerin bu süreçteki rolünü tanıma niyetinde olduğu şeklinde yorumlanabilir. Anlaşma, henüz onaylanmayıp Resmi Gazete'de yayımlanmaması sebebiyle Anayasanın 90. maddesinde belirtilen "kanun hükmünde" niteliğini kazanmamıştır. Bununla birlikte bu durumun yakın gelecekte değişmesi beklenmektedir. Gerek Türkiye'nin uluslararası sorumlukları gerek BBS'nin yaygınlaşması ve İstanbul'daki bazı belediyelerin bu oluşumda yerini alması nedeniyle diğer belediyeler gibi Ümraniye Belediyesinin de gelecekte bu hesaplamayı yapma ve eylem planı oluşturma yükümlülügü altına girmesi kuvvetli bir ihtimaldir.

Bu bağlamda, iklim değişikliğine kentlerin olumsuz etkisinin belirlenmesi için, Ümraniye ilçesi sınırları içinde gerçekleştirilen bu çalışma ile diğer yerel yönetim birimlerine yol gösterecek bir yaklaşım geliştirilmesi hedeflenmiştir. Bu sebeple, kolaylıkla takip edilebilmesi amacıyla yapılan hesaplamalar detaylıca aktarılııștır. Ancak karbon ayak izinin belirlenmesi hesabı kullanılan parametreler ve verilerin detaylandırılmasına bağlı olarak gün geçtikçe geliştirilmektedir. $\mathrm{Bu}$ çalışmanın da en geliştirilmiş hesap yöntemini ortaya koymak iddiası olmayıp, çalışmanın karbon ayak izinin belirlenmesinde basit ve yaygın olarak kullanılabilecek bir yaklaşım geliştirme hedefi bulunmaktadır. Ayrıca mevcut çalışma ile karbon ayak izinin belirlenmesinden sonraki eylem planlarının hazırlanması adımında ihtiyaç duyulan "nerede, ne şekilde önlem alınması" sorularına ışık tutulacağı düşünülmektedir. Bu kapsamda Ümraniye ilçesindeki karbon ayak izi hesaplanırken, ilçedeki konutlar, sanayiler, ticarethane ve resmi kurumlarda (hastane, okul, vb.) doğalgaz, kömür ve elektrik tüketimi ile ulaşımdan kaynaklanan emisyonlar dikkate alınmıştır. Hesaplama için gereken veriler ulusal-yerel kurum ve kuruluşlardan elde edilmiştir. Hesaplama yöntemleri ve emisyon faktörlerinin belirlenmesinde ise IEAP, Sera Gazı Emisyonlarının İzlenmesi ve Raporlanması Hakkında Tebliği (22.07.2014 tarihli ve 29068 sayıll) ile daha önce bu konuda yapılmış çalışmalardan faydalanılmıştır (ICLEI 2009; IBBB 2015; Pendik Belediyesi 2015; Kadıköy Belediyesi 2014). Nihayetinde bu çalışmada yapılan tespitlerin ve izlenen yaklaşımın yalnızca Ümraniye Belediyesi için değil, diğer yerel yönetim birimleri için de küresel ısınmayla mücadelede mevcut durum tespiti olan ilk adımı oluşturmada yararlı olacağı umulmaktadır.

\section{Materyal ve Yöntem}

\section{1.Ümraniye ilçesi}

İstanbul'un Anadolu yakasındaki ilçelerden birisi olan Ümraniye, kuzeyden Çekmeköy ve Beykoz, güneyden Ataşehir, doğudan Sancaktepe, batıdan Üsküdar ile komşudur. İlçenin yüzölçümü 4.538 hektardır (Ümraniye Belediyesi 2019a). TÜiK'in 2017 verilerine göre Ümraniye, İstanbul'un en kalabalık dördüncü ilçesi olup, toplam nüfus 699.901 kişidir (TÜIK 2018a). TÜIK 2017 yılı verilerine göre ilçede yaşayanlardan \%47'sinin Anadolu'daki başka il ve ilçelerin nüfuslarına kayıtlı olduğu belirlenmiştir (TÜiK 2018a). 2017 yılında \%47 olarak tespit edilen bu oranın, 2010 yılında yapılan bir çalışmada \%33 olduğu gözlenmiştir (Gürel ve Balta 2011). Bu durum karşısında, zamanla, ilçeye başka şehirlerden gelenlerin sayısının daha da artacağı tahmin edilmektedir. 
İlçedeki beklenen nüfus artışı ile ilgili TÜBİTAK MAM tarafından gerçekleştirilen bir çalışmada, ilçenin yıllık nüfus artış oranı \%1,94; 2040 yılı için nüfus değeri 835.266 kişi olarak tespit edilmiştir (TÜBİTAK MAM 2010).

İlçe sınırları içerisinde 224.053 adet konut, 50.645 adet işyeri, 53.862 adet bina yer almaktadır (Ümraniye Belediyesi 2019a). İlçe sınırları içerisinde yer alan 35 mahallede ortalama nüfus 20.000 civarı olup, en yüksek nüfusa sahip mahaller İstiklal, Çakmak ve Armağanevler'dir (Ümraniye Belediyesi 2019b). Ümraniye Belediyesinden 04.07.2019 tarihinde alınan bilgiler doğrultusunda, belediyenin ana hizmet binası dışında 39 adet sosyal ve kültürel amaçlı hizmet binaları yer almaktadır. Bunlar kültür merkezi, bilgi evi, spor salonu ve sosyal tesis olarak sınıflanmaktadır. Ümraniye Belediyesine ait resmi ve kiralık olmak üzere toplam 535 araç ve iş makinası bulunmaktadır. Bunlar 58 adet iş makinası, 157 adet binek araç, 133 adet otobüs ve minibüs ile 187 adet tır, kamyon ve kamyonet olarak sıralanmaktadır (Ümraniye Belediyesi 2019c). Ümraniye ilçesinde toplanan evsel atıklar ilçe sınırları içerisinde bertaraf edilmeyip, transfer istasyonunda toplandıktan sonra Şile'de yer alan Kömürcüoda'ya taşınmakta ve burada düzenli olarak depolanmaktadır. Belediye tarafından kullanılan kamyon ve kamyonetlerin önemli bir kısmı ilçedeki evsel atığı toplama amaçlıdır.

Ümraniye'de sanayinin gelişmesinde tüketiciye yakınlık ve ulaşım kolaylığı etkili olmuştur. Hammaddeye ve enerji kaynaklarına olan uzaklığına rağmen bunlara erişimi sağlayan ulaşımın gelişmesi sanayi gelişimini hızlandırmıştır. Tuzla ve Haydarpaşa Limanları, E-80 ve D-100 otoyolları ile Sabiha Gökçen Havaalanını kapsayan ulaşım ağı Ümraniye'ye sanayi açısından olumlu etkide bulunmuştur (Temurçin ve Aldırmaz 2014). İstanbul'daki endüstriyel faaliyetlerin \%6’sının Ümraniye'de gerçekleştiği belirlenmiştir. Ümraniye'deki üretim yerlerinden yaklaşık \%60'ının küçük ölçekli, kalanın orta ve büyük ölçekli olduğu tespit edilmiştir (Temurçin ve Aldırmaz 2014).

\subsection{Karbon Ayak İzinin Belirlenmesi Metodolojisi}

Karbon ayak izinin belirlenmesinde, insan faaliyetlerinin çevreye verdiği zararın ölçüsü olarak üretilen sera gazı miktarı, birim karbondioksit cinsinden hesaplanmaktadır. IPCC'ye göre karbon ayak izi birincil ve ikincil olmak üzere iki farklı kategoride incelenmektedir. Birincil karbon ayak izi (doğrudan karbon ayak izi) enerji tüketimi ve ulaştırma faaliyetlerine bağlı olarak tüketilen fosil yakıtları sonucu oluşan $\mathrm{CO}_{2}$ emisyonlarını tanımlarken; İkincil karbon ayak izi (dolaylı karbon ayak izi) kullanılan tüm ürünlerin üretilminden bozulma sürecine kadar olan yaşam döngüsü içinde oluşan $\mathrm{CO}_{2}$ emisyonlarını tanımlamaktadır (IPCC 2006). Ürünlerin yaşam döngüsü dikkate alındığında, ikincil karbon ayak izinin içinde birincil karbon ayak izinin yer aldığı görülmektedir.

Bu çalışmada Ümraniye ilçesi sınırları içinde gerçekleşen faaliyetlerden kaynaklanan salınımı belirlemek amacıyla birincil karbon ayak izinin hesaplanması hedeflenmiştir. Hesaplamalarda Yerel Yönetimler için sera gazı salımlarının analizinde uluslararası ölçekte yol gösterici olan IEAP esas alınmıştır. IEAP'ta IPCC kılavuzları, Dünya Kaynakları Enstitüsü (WRI) / Dünya Sürdürülebilir Kalkınma İş Konseyi (WBCSD) Greenhouse Gases (GHG) Protokolü, ISO 14064 GHG Standart serisi ve Global Reporting Initiative (GRI) Kamu Sektörü Kurumları Eki temel alınmaktadır. Bu kaynaklardan ISO 14064 GHG Standart serisinden yöntemlerin belirlenmesinde; GHG Protokolünden hesaplamaların gerçekleştirilmesinde; IPCC kılavuzlarından ise verinin toplanması, hesaplanması, raporlanması ve referans değer tablolarının kullanılmasında yararlanılmıştır.

Mevcut çalışmada esas alınan IEAP'de karbon ayak izinin belirlenmesi kapsam 1, kapsam 2 ve kapsam 3 olmak üzere üç farklı kategoride değerlendirilmektedir. Kapsam 1, bölgedeki yakıt tüketimleri sonucu oluşan doğrudan gaz salınımlarını; Kapsam 2, bölgede tüketilen ancak bölge dışında üretimi yapılan dolaylı salınımları; Kapsam 3 ise bölgede tüketilen ürün ve hizmetlerin üretimi ve nakliyesi sebebiyle diğer bölgelerde ortaya çıkan dolaylı salınımları ifade etmektedir. Bu sınıflandırmaya örnek olmak üzere, Kapsam 1'de 1sınma amaçlı yakıt tüketimi (doğalgaz, kömür gibi) ve özellikle kara taşıtları başta olmak üzere ilçe içi ulaşım kaynaklı yakıt tüketimi dikkate alınmaktadır. Kapsam 2'de konut, endüstri ve ticarethaneler ile sokak aydınlatmalarında kullanılan elektrik tüketimi değerlendirilmektedir. Kapsam 3 'te ise bölge sınırları dışında bertaraf edilen bölge halkı kaynaklı atıklar ve havayolu ulaşımı incelenmektedir (Tablo 1). Mevcut çalışmada, ilçe içindeki faaliyetler dikkate alınarak yalnızca Kapsam 1 ve Kapsam 2 dikkate alınmıştır. Kapsam 3’ün hesaba dahil edilmemesinin sebebi ilçe sınırları içerisinde havalimanı olmaması ve ilçede nihai atık bertarafı yapılmamasıdır. İlçede toplanan atıklar önce transfer istasyonunda toplanmakta ardından ilçe dışına taşınmaktadır. Atıkların transferi sırasında kullanılan kamyon ve kamyonetlerin emisyonları Belediye araçları içerisinde Kapsam 1 olarak hesaba dahil edilmiştir. Bunun dışında Ümraniye'de sera gazı tutma veya uzaklaştırma amaçlı, dikkate alınabilecek park ve bahçe gibi yutak alanlar mevcuttur. Ancak bu alanlardaki ağaç ve bitki sayısı, cinsi, yaşı gibi verilere ulaşılamamış dolayısıyla çalışmanın kapsamı dışında bırakılmıştır.

IEAP'ya göre envanterde yer alması gereken sera gazları sırasıyla karbondioksit $\left(\mathrm{CO}_{2}\right)$, metan $\left(\mathrm{CH}_{4}\right)$, diazot monoksit $\left(\mathrm{N}_{2} \mathrm{O}\right)$, perflorokarbonlar (PFCs), hidroflorokarbonlar (HFCs) ve sülfürheksaflorid ( $\mathrm{SF}_{6}$ ) olarak belirlenmiştir (ICLEI 2009). Bu gazların bir kısmının doğal yollarla oluşmasının yanı sıra, önemli ölçüde insan faaliyetlerinden kaynaklandığı tespit edilmiştir. Sera gazlarının küresel ısınmadaki rolü yalnızca miktarları üzerinden değil, atmosferdeki kalış süreleri ve enerjiyi tutma kapasiteleri üzerinden belirlenmektedir. Bu duruma örnek olmak üzere gazlar arasında $\mathrm{CH}_{4}$ 'nın küresel ısınma potansiyeli $\mathrm{CO}_{2}$ 'in 21 kat üzerindedir. Ancak $\mathrm{CO}_{2}$ üretimi diğer gazlara oranla çok daha fazladır. Yapılan hesaplamalara göre insan faaliyetleri sonucu oluşan $\mathrm{CO}_{2}$ 'in sera etkisi içindeki payı \%55 olarak belirlenmiştir. Bu sebepten $\mathrm{CO}_{2}$ salınımı sera etkisinin başlıca nedeni olarak kabul edilmektedir (Dulkadiroğlu 2018). 
TÜİK tarafından Türkiye genelinde sera gazı salınımı için yapılan değerlendirmede, 2016 yılında salınan sera gazları arasında $\mathrm{CO}_{2}$ 'in etkisi \%81 olarak belirlenmiştir. Ardından $\mathrm{CH}_{4}(\% 11), \mathrm{N}_{2} \mathrm{O}(\% 6)$ ve $\mathrm{F}$ gazları (\%1) gelmiştir (TÜIKK 2018b). Buna göre küresel ısınmaya etki eden sera gazlarının belirlenmesinde, hesaplama kolaylığı açısından tüm sera gazlarının etkileri $\mathrm{CO}_{2}$ eş değerine dönüştürülerek belirtilmektedir. Mevcut çalışmada yapılan hesaplamalarda da sera gazları $\mathrm{CO}_{2}$ eşdeğeri üzerinden değerlendirilmiştir.

Tablo 1: IEAP'ye göre sera gazı salınımlarının sınıflandırılması

\begin{tabular}{|c|c|}
\hline Kapsam & Emisyon Kaynağı \\
\hline \multicolumn{2}{|c|}{ Kapsam 1 (Doğrudan Emisyon) } \\
\hline \multirow[t]{2}{*}{ Konut } & Doğalgaz Tüketimi \\
\hline & Kömür Tüketimi \\
\hline Sanayi & Doğalgaz Tüketimi \\
\hline Ticarethane ve Kurumlar & Doğalgaz Tüketimi \\
\hline \multirow[t]{3}{*}{ Ulaşım } & Benzin Tüketimi \\
\hline & Motorin Tüketimi \\
\hline & LPG Tüketimi \\
\hline \multicolumn{2}{|c|}{ Kapsam 2 (Dolaylı Emisyon) } \\
\hline Konut & Elektrik Tüketimi \\
\hline Sanayi & Elektrik Tüketimi \\
\hline Ticarethane ve Kurumlar & Elektrik Tüketimi \\
\hline Aydinlatma & Elektrik Tüketimi \\
\hline Ulaşım & Elektrik Tüketimi \\
\hline \multicolumn{2}{|c|}{ Kapsam 3 (Diğer Bölgelerde Ortaya Çıkan Dolaylı Emisyon) } \\
\hline Konut & Atık Oluşumu \\
\hline Ulaşım & Uçuş Kaynaklı Yakıt Tüketimi \\
\hline
\end{tabular}

Çalışmada kullanılan tüketim verilerinin çoğu (ilçedeki elektrik, doğalgaz tüketimleri ve Belediyenin kendine ait tüketimleri) resmi kurumlardan temin edilmiştir. Hesaplamalar yapılırken yakılan yakıt türü, miktarı ve kullanılan emisyon faktörü bilgisinin detayına göre Tier 1, Tier 2 veya Tier 3 yaklaşımları kullanılabilmektedir. Tier 1 yaklaşımında, yakıtın kullanıldığı yanma teknolojisi hakkında bilgi sahibi olmak gerekmeksizin, ulusal enerji istatistikleri kullanılarak elde edilen genel bir sonuca ulaşılabilirken; Tier 2 yaklaşımında yakıtın yanma teknolojisi dikkate alınarak, ülkeye veya belirli gölgeye göre belirlenen özel emisyon faktörleri kullanılmakta ve daha hassas değerlere ulaşılabilmektedir. Tier 3 yaklaşımında ise yakıtın yanmasıyla ilgili daha detaylı veri (beslenme tipi, yakma tesislerinin ısıl güçleri, vb.) kullanılarak hesaplamalar yapılmaktadır (REC 2009). Mevcut çalışmada olabildiğince Tier 2 yaklaşımı kullanılmakla birlikte, temin edilen veri niteliğine göre Tier 1 yaklaşımı da kullanılmıştır. Tier 3 yaklaşımı ise ayrıntılı bilgiye ihtiyaç duyulması ve buna ulaşılamaması sebebi ile kullanılamamıştır.

Çalışmada yapılan hesaplamalar karbondioksit eşdeğeri üzerinden 2017 yılı tüketim verileri esas alınarak yapılmıştır. Hesaplamalarda belediyenin kendi faaliyetlerinden kaynaklanan emisyonların belirlenmesinde, Ümraniye Belediyesi'ne ait 2017 yılı elektrik ve doğalgaz tüketim verileri ile belediyenin kullandığı araçların benzin ve motorin tüketimleri dikkate alınmıştır. İlçe sınırları içerisindeki konut, sanayi, ticarethane ve resmi kurumlardan kaynaklanan emisyonların belirlenmesinde elektrik tüketimi için 15.08.2018 tarihinde temin edilen AYEDAŞ verileri ile Enerji Piyasası Düzenleme Kurumu (EPDK) Sektör Raporlarından (EPDK 2018a); doğalgaz tüketimi içinse 15.06.2018 tarihinde temin edilen İGDAŞ verilerinden yararlanılmıştır. Hesaplamalarda kullanılan emisyon faktörü için TÜİK tarafından hazırlanan Ulusal Envanter Bildirim Raporu (TÜİK 2018c) ile İstanbul Büyükşehir Belediyesi, İstanbul İklim Değişikliği Eylem Planı Sera Gazı Envanteri (İBB 2015) yer alan değerler esas alınmıştır. IEAP doğrultusunda doğalgaz ve elektrik tüketimi kaynaklı emisyonlar aşağıdaki formüle bağlı kalınarak hesaplanmıştır:

$C S=T M \times E F$

Burada $C S$; söz konusu faaliyetten kaynaklanan $\mathrm{CO}_{2}$ salınımını, $T M$; tüketim miktarını (faaliyet verisini), $E F$; emisyon faktörünü (tüketime veya yakıta özel) ifade etmektedir.

01-15.07.2018 tarihinde Ümraniye Belediyesi ile yapılan görüşmelerden ilçedeki nüfusun yaklaşık \%20’sinin kömür kullandığı bilgisine ulaşılmıştır. Yaklaşık 150.000 kişiye karşılık gelen bu nüfus için bir hanede dört kişi olacağı kabulü yapılarak 30.000 hanenin kömür tüketimi esas alınmıştır. Mevcut çalışmadaki hesaplamalarda, hane başına kömür tüketiminin ise 1,5 ton/yıl olduğu ve yılda beş ay kömür tüketimi olduğu varsayılmıştır. Kömür kullanımı kaynaklı $\mathrm{CO}_{2}$ salınımı hesaplamalarında ise 1000 ton kömür tüketimine karşılık 2851,9 ton $\mathrm{CO}_{2}$ salınımı olduğu kabulü (Atabey 2013) yapılmıştır. 
İlçe sınırları içerisindeki ulaşımdan kaynaklanan $\mathrm{CO}_{2}$ salınımlarının belirlenmesinde araçların sayıları, kullandıkları yakıtların cinsleri, yakıt tüketim miktarları ve yakıtın karbon içeriği dikkate alınmıştır. Hesaplamalarda mümkün olduğunca, daha detaylı yaklaşım olan IPCC Kılavuzundaki ikinci yaklaşım (Tier 2) kullanılmıştır.

Hesaplamalarda kullanılan "emisyon faktörü" nün belirlenmesinde TÜİK tarafindan hazırlanan Ulusal Sera Gazı Envanter Bildirim Raporu (TÜIK 2018c) ile Çevre ve Şehircilik Bakanlığı tarafından yayımlanan Sera Gazı Emisyonlarının İzlenmesi ve Raporlanması Hakkında Tebliği Ek-5'inde (22.07.2014 tarihli ve 29068 sayılı) yer alan değerler esas alınmıştır.

Ulaşımda toplu taşıma araçlarından otobüsler için İETT Çevre ve Enerji Genel Müdürlüğünden 15.06.2018 tarihinde veri temin edilmiş ve İETT karbon ayak izi hesaplama aracından (IETT 2018) yararlanılmıştır. Yapılan hesaplamalarda göz ardı edilebilen otobüs seferleri olduğu dikkate alınarak, elde edilen değerler güvenli tarafta kalmak amacıyla \%25 oranında arttııılmıştır. Minibüsler için 15.06.2018 tarihinde Toplu Ulaşım Hizmetleri Müdürlüğünden (TUHIM) Ümraniye ilçesindeki minibüs sayıları ve yakıt tüketim değerleri alınmıştır.

Otomobil kaynaklı $\mathrm{CO}_{2}$ salınımlarının belirlenmesinde, yalnızca ilçeye kayıtlı otomobilin değil, aynı zamanda ilçeden geçen otomobillerin de değerlendirmeye katılması için yakıt tüketimi üzerinden gidilmiştir. Otomobillerin yakıt tüketimleri, EPDK Yı1lık Petrol Piyasası Raporu'nda yer alan illere göre yurt içi satış değerlerinden elde edilmiştir (EPDK 2018b). Bu veri İstanbul ölçeğinde olup, Ümraniye'deki araçların yakıt tüketimlerine ulaşmak için nüfus üzerinden oranlama yapılmıştır. Ancak daha detaylı sonucu ulaşabilmek için TÜiK'ten 15-30.06.2018 tarihlerinde temin edilen ilçede kayıtlı yakıt türene göre araç sayısı oranları da dikkate alınmıştır.

Ümraniye'den geçen kamyon ve kamyonetlerin salınımları hesaplanırken; aldıkları mesafe, kullandıkları yakıt ve araç sayısı dikkate alınmıştır. Bir kamyonun Ümraniye sınırları içerisinde aldığı yol Ümraniye sınırlarındaki en uzun mesafe olan $12 \mathrm{~km}$ olarak ele alınmıştır. Ümraniye ilçesine kayıtlı kamyon ve sayısı ise 15-30.06.2018 tarihlerinde TÜIK'ten temin edilmiştir. Ümraniye sınırlarından geçen metro kaynaklı $\mathrm{CO}_{2}$ salınımı ise İstanbul genelinde raylı sistem için tespit edilen toplam yıllık elektrik tüketimi değerinin ilçe sınırlarından geçen metro hattının uzunluğuna oranlanmasıyla hesaplanmıştır (Metro 2018). Hesaplamalarda kullanılan araç türleri ve yakıt cinsine göre 100 km'deki yakıt tüketim değerleri Tablo 2'de özetlenmektedir.

Tablo 2: Mevcut çalışmada Ümraniye'deki araçların 100 km'deki yakıt tüketimleri için kullanılan değerler

\begin{tabular}{|l|c|c|c|c|c|c|c|c|c|c|}
\hline \multirow{2}{*}{$\begin{array}{c}\text { Araç } \\
\text { Türü }\end{array}$} & \multicolumn{3}{|c|}{ Toplu Taşıma } & \multicolumn{4}{c|}{ Özel Araç } & \multicolumn{3}{c|}{ Ticari Araçlar* } \\
\cline { 2 - 10 } & Otobüs & $\begin{array}{c}\text { Hatlı } \\
\text { minibüs }\end{array}$ & Metro & \multicolumn{3}{|c|}{ Otomobil } & Motosiklet & $\begin{array}{c}\text { Ticari } \\
\text { Minibüsler }\end{array}$ & Kamyon & Kamyonet \\
\hline $\begin{array}{l}\text { Yakıt } \\
\text { Türü }\end{array}$ & Motorin & Motorin & Elektrik & Benzin* & Motorin* & LPG* & Benzin* & Motorin & Motorin* & Motorin* \\
\cline { 2 - 10 } & 54,0 & 13,0 & - & 8,5 & 7,3 & 11,2 & 4,0 & 13,0 & 29,9 & 10,9 \\
\hline
\end{tabular}

Ulaşım kaynaklı emisyonlar aşağıdaki formüllere bağlı kalarak hesaplanmıştır. İETT Otobüs seferleri kaynaklı emisyonlar için:

$C S=V x K S \times S S x A O$

Burada CS; Ümraniye sınırları içinden geçen İETT otobüsleri kaynaklı $\mathrm{CO}_{2}$ salınımını $\left(\mathrm{kg} \mathrm{CO}_{2} \mathrm{e} / \mathrm{y} 1\right), V$; IETT Hesap aracından alınan veriyi (gr $\mathrm{CO}_{2} /$ kişi.araç), $K S$; bir otobüste yolculuk yapan kişi sayısını (60 kişi/araç olarak kabul edilmiştir), $S S$; otobüsün sefer sayısını, $A O$; bilinmeyenler için alınan artırma oranını (\%25 olarak alınmıştır) ifade etmektedir. Minibüsler ve özel araçlar kaynaklı emisyonlar için:

$C S=Y T \times E M$

$Y T=A S \times M \times Y T$

Burada $C S$; Ümraniye sınırlarından geçen minibüsler ve özel araçlar kaynaklı $\mathrm{CO}_{2}$ salınımını $\left(\mathrm{kg} \mathrm{CO}_{2} \mathrm{e} / \mathrm{yl} \mathrm{l}\right), E F$; emisyon faktörünü $\left(\mathrm{kg} \mathrm{CO}_{2} \mathrm{e} / \mathrm{L}\right), Y T$; Ümraniye ilçesine kayıtlı araçların toplam yakıt tüketimini (L/yıl), $A S$; araç sayısını, $M$; bir aracın aldığı mesafeyi $(\mathrm{km} / \mathrm{y} ı 1), Y T$; bir aracın yakıt tüketimini $(\mathrm{L} / \mathrm{km})$ ifade etmektedir. Metrodan kaynaklanan emisyonlar için:

$C S=E T \times H U O \times E F$

Burada CS; Ümraniye sınırlarından geçen metro kaynaklı $\mathrm{CO}_{2}$ salınımını $\left(\mathrm{kg} \mathrm{CO}_{2} \mathrm{e} / \mathrm{y} ı 1\right), E T$; İstanbul genelinde raylı sistem için yıllık elektrik tüketimini $(\mathrm{kWh}), H U O$; Ümraniye sınırlarından geçen metro hattı uzunluğunun, İstanbul'daki metro hattı uzunluğuna olan oranını, $E F$; Emisyon Faktörünü $\left(\mathrm{kg} \mathrm{CO}_{2} \mathrm{e} / \mathrm{kWh}\right)$ ifade etmektedir. 
Yukarıda bahsi geçen emisyon kaynakları (konut, sanayi, ticarethane ve resmi kurumlar ile ulaşım) için mevcut çalışmada kullanılan tüketim miktarları, emisyon faktörleri ve hesap yöntemleri Tablo 3'te özetlenmektedir. Emisyon faktörleri TÜİK tarafından hazırlanan Ulusal Sera Gazı Envanter Bildirim Raporu (TÜİK 2018c) ile Çevre ve Şehircilik Bakanlığı tarafından yayımlanan Sera Gazı Emisyonlarının İzlenmesi ve Raporlanması Hakkında Tebliği'in Ek-5'inde (22.07.2014 tarihli ve 29068 sayılı) yer alan değerler esas alınmıştır.

Tablo 3: Ümraniye ilçesi sınırları içerisinde oluşan $\mathrm{CO}_{2}$ salınımının belirlenmesinde kullanılan değerler ve hesaplama yöntemi

\begin{tabular}{|c|c|c|c|c|c|c|c|c|}
\hline \multicolumn{2}{|c|}{ Emisyon Kaynağı } & \multirow{2}{*}{$\begin{array}{c}\begin{array}{c}\text { Tüketim } \\
\text { Verisi } \\
\text { Kaynağı }\end{array} \\
\text { AYEDAŞ }\end{array}$} & \multirow{2}{*}{$\begin{array}{c}\begin{array}{c}\text { Kullanıla } \\
\text { n Yakıt/ } \\
\text { Enerji }\end{array} \\
\text { Elektrik }\end{array}$} & \multicolumn{2}{|c|}{$\begin{array}{l}\text { Yakıt/Enerji Tüketim } \\
\text { Miktarı (2017) }\end{array}$} & \multicolumn{2}{|c|}{$\begin{array}{c}\text { Kullanılan Emisyon } \\
\text { Faktörü }\end{array}$} & \multirow{2}{*}{$\begin{array}{c}\begin{array}{c}\text { Emisyon } \\
\text { Hesaplama } \\
\text { Yöntemi }\end{array} \\
\text { Denklem 1 }\end{array}$} \\
\hline \multirow{3}{*}{\multicolumn{2}{|c|}{ Konut }} & & & 890.624 .847 & $\mathrm{kWh}$ & 0,495 & $\mathrm{~kg} \mathrm{CO} 2 \mathrm{e} / \mathrm{kWh}$ & \\
\hline & & İGDAŞ & Doğalgaz & 210.360 .902 & $\mathrm{Sm}^{3}$ & 0,202 & $\mathrm{~kg} \mathrm{CO}_{2} / \mathrm{kWh}^{*}$ & Denklem 1 \\
\hline & & Belediye & Kömür & 1,5 & $\begin{array}{r}\text { ton } / \mathrm{y} 11 \\
\text {.hane }\end{array}$ & 2,852 & $\mathrm{~kg} \mathrm{CO}_{2} / \mathrm{kg}$ & Denklem 1 \\
\hline \multicolumn{2}{|c|}{ Sokak Aydınlatma } & AYEDAŞ & Elektrik & 35.952 .033 & $\mathrm{kWh}$ & 0,495 & $\mathrm{~kg} \mathrm{CO} 2 \mathrm{e} / \mathrm{kWh}$ & Denklem 1 \\
\hline \multirow{2}{*}{\multicolumn{2}{|c|}{ Sanayi }} & AYEDAŞ & Elektrik & 111.079 .847 & $\mathrm{kWh}$ & 0,495 & $\mathrm{~kg} \mathrm{CO}_{2} \mathrm{e} / \mathrm{kWh}$ & Denklem 1 \\
\hline & & İGDAŞ & Doğalgaz & 10.511 .876 & $\mathrm{~m}^{3} / \mathrm{y} 1 \mathrm{l}$ & 0,202 & $\mathrm{~kg} \mathrm{CO}_{2} / \mathrm{kWh}^{*}$ & Denklem 1 \\
\hline \multirow{2}{*}{\multicolumn{2}{|c|}{$\begin{array}{l}\text { Ticarethaneler ve } \\
\text { Resmi Kurumlar }\end{array}$}} & AYEDAŞ & Elektrik & 1.170 .135 .277 & $\mathrm{kWh}$ & 0,495 & $\mathrm{~kg} \mathrm{CO}_{2} \mathrm{e} / \mathrm{kWh}$ & Denklem 1 \\
\hline & & İGDAŞ & Doğalgaz & 61.902 .646 & $\mathrm{Sm}^{3}$ & 0,202 & $\mathrm{~kg} \mathrm{CO}_{2} / \mathrm{kWh}^{*}$ & Denklem 1 \\
\hline \multirow{10}{*}{ Ulaşım } & Otobüs & İETT** & Motorin & 150.000 .000 & $\mathrm{~L} / \mathrm{y} 1 \mathrm{l}$ & - & $\mathrm{kg} \mathrm{CO} 2 \mathrm{e} / \mathrm{L}$ & Denklem 2 \\
\hline & \multirow{3}{*}{ Otomobil } & TÜİK & Benzin & 18.914 .956 & $\mathrm{~L} / \mathrm{y} 1 \mathrm{l}$ & 2,404 & $\mathrm{~kg} \mathrm{CO} 2 \mathrm{e} / \mathrm{L}$ & Denklem 3 \\
\hline & & TÜİK & Motorin & 28.868 .839 & $\mathrm{~L} / \mathrm{y} 1 \mathrm{l}$ & 2,687 & $\mathrm{~kg} \mathrm{CO} 2 \mathrm{e} / \mathrm{L}$ & Denklem 3 \\
\hline & & TÜİK & LPG & 14.226 .985 & $\mathrm{~L} / \mathrm{y} 1 \mathrm{l}$ & 1,640 & $\mathrm{~kg} \mathrm{CO} \mathrm{e}_{2} / \mathrm{L}$ & Denklem 3 \\
\hline & $\begin{array}{l}\text { Ticari } \\
\text { Minibüs }\end{array}$ & TUHİM & Motorin & 13.744 .500 & $\mathrm{~L} / \mathrm{y} 1 \mathrm{l}$ & 2,687 & $\mathrm{~kg} \mathrm{CO} \mathrm{C}_{2} \mathrm{e} / \mathrm{L}$ & Denklem 3 \\
\hline & Minibüs & TÜİK & Motorin & 262.800 & $\mathrm{~L} / \mathrm{y} 1 \mathrm{l}$ & 2,687 & $\mathrm{~kg} \mathrm{CO} 2 \mathrm{e} / \mathrm{L}$ & Denklem 3 \\
\hline & Kamyon & TÜİK & Motorin & 5.967 .969 & $\mathrm{~L} / \mathrm{y} 1 \mathrm{l}$ & 2,687 & $\mathrm{~kg} \mathrm{CO} \mathrm{e}_{2} / \mathrm{L}$ & Denklem 3 \\
\hline & Kamyonet & TÜİK & Motorin & 27.837 .440 & $\mathrm{~L} / \mathrm{y} 1 \mathrm{l}$ & 2,687 & $\mathrm{~kg} \mathrm{CO} 2 \mathrm{e} / \mathrm{L}$ & Denklem 3 \\
\hline & Motosiklet & TÜİK & Motorin & 2.599 .072 & $\mathrm{~L} / \mathrm{y} 1 \mathrm{l}$ & 2,687 & $\mathrm{~kg} \mathrm{CO} \mathrm{e}_{2} / \mathrm{L}$ & Denklem 3 \\
\hline & \begin{tabular}{|l|} 
Raylı \\
system
\end{tabular} & İBB & Elektrik & 6.452 .178 & $\mathrm{kWh} / \mathrm{y} 1 \mathrm{l}$ & 0,495 & $\mathrm{~kg} \mathrm{CO}_{2} \mathrm{e} / \mathrm{kWh}$ & Denklem 5 \\
\hline \multirow{4}{*}{\multicolumn{2}{|c|}{$\begin{array}{l}\text { Belediyenin Kendi } \\
\text { Hizmetleri }\end{array}$}} & Belediye & Elektrik & 6.224 .000 & $\mathrm{kWh}$ & 0,495 & $\mathrm{~kg} \mathrm{CO} 2 \mathrm{e} / \mathrm{kWh}$ & Denklem 1 \\
\hline & & Belediye & Doğalgaz & 2.264 .091 & $\mathrm{Sm}^{3}$ & 0,202 & $\mathrm{~kg} \mathrm{CO}_{2} / \mathrm{kWh}^{*}$ & Denklem 1 \\
\hline & & Belediye & Benzin & 15.608 & $\mathrm{~L} / \mathrm{y} 1 \mathrm{l}$ & 2,404 & $\mathrm{~kg} \mathrm{CO} 2 \mathrm{e} / \mathrm{L}$ & Denklem 3 \\
\hline & & Belediye & Motorin & 2.618 .266 & $\mathrm{~L} / \mathrm{y} 1 \mathrm{l}$ & 2,687 & $\mathrm{~kg} \mathrm{CO} \mathrm{e}_{2} / \mathrm{L}$ & Denklem 3 \\
\hline
\end{tabular}

\section{Bulgular ve Tartışma}

Ümraniye Belediyesi'nin karbon ayak izi belirlenirken, ilçe sınırlarındaki konut, sanayi, ticarethane ve resmi kurumlardaki tüketimler ile ulaşım dikkate alınmıştır. Bu kapsamda 2017 yılının tüketim değerleri esas alınarak, sabit kaynaklar olan konut, sanayi, ticarethane ve resmi kurumlar için 1sınma amaçlı kullanılan doğalgaz ve kömür ile elektrik tüketimleri incelenmiştir. Yayılı kaynak olan ulaşım için toplu taşıma ve özel araçların güzergahları (mesafe uzunlukları), yakıt cinsleri (benzin, motorin ve LPG) ve tüketimleri üzerinden hesaplamalar yapılmıştır. Ayrıca belediyenin kendi faaliyetlerinden kaynaklanan emisyonlar da belirlenmiştir. Hesaplamalar aşağıda detaylı olarak sunulmaktadır.

\section{1.Ümraniye İlçesinde Karbon Ayak İzinin Kaynaklarına Göre Dağılımı}

\subsubsection{Konutlar}

Konutlarda Isınma Kaynaklı $\mathrm{CO}_{2}$ Salınımı: Konutlarda özellikle 1sınma amaçlı fosil yakıt tüketimine bağlı sera gazı salınımları değerlendirilirken Ümraniye sınırları içerisinde kullanılan kömür ve doğalgaz dikkate alınmıştır. Hesaplamalarda, doğalgaz dağıtım hattındaki olası sızıntılar ihmal edilerek, doğalgaz arzının \%100'ünün tüketildiği varsayılmıştır. 01-15.07.2018 tarihinde Ümraniye Belediyesi ile yapılan görüşmelerde ilçedeki toplam nüfusun yaklaşık \%20’sinin kömür kullandığı beyan edilmiştir. Yapılan hesaplamalar sonucu ilçedeki kömür tüketimi kaynaklı salınımın 12.834 ton/yıl, doğalgaz tüketimi kaynaklı salınımın ise 407.507 ton/yıl $\mathrm{CO}_{2}$ eşdeğeri olduğu belirlenmiştir. 
Bir diğer ifadeyle, ilçedeki konutlarda 1sınma kaynaklı toplam sera gazı salınımı 420.340 ton/yıl $\mathrm{CO}_{2}$ eşdeğeri olarak tespit edilmiştir. Elde edilen bu değer, 2015 yılında İstanbul genelinde hesaplanan, konutlardaki doğalgaz salınımı (7.680.593 ton/yıl $\mathrm{CO}_{2}$ eşdeğeri; İBB 2015) ile karşılaştırıldığında; ilçedeki emisyonun, İstanbul genelinin yaklaşık $\% 5$ 'ini oluşturduğu görülmektedir.

Ümraniye nüfusunun İstanbul genelindeki nüfusa olan oranının da yaklaşık \%5 olduğu dikkate alındığında, elde edilen sonucun anlamlı olduğu düşünülmektedir. Bununla birlikte nüfus, bölge, yaşayan profili gibi yaklaşık benzer karakterlere sahip Pendik ilçesi için doğalgaz kullanımı kaynaklı $\mathrm{CO}_{2}$ salınımı 259.775 ton/yıl, kömür kullanımı kaynaklı $\mathrm{CO}_{2}$ salınımı 33,7 ton/yıl olarak hesaplanmıştır (Pendik Belediyesi 2015). Bu sonuca göre Ümraniye'deki tüketimin Pendik’ten yüksek olduğu görülmektedir.

Konutlarda Elektrik Tüketimi Kaynaklı $\mathrm{CO}_{2}$ Salınımı: Ümraniye ilçesi sınırları içerisindeki konutlarda elektrik tüketimi kaynaklı $\mathrm{CO}_{2}$ salınımı hesaplanırken iki ayrı yöntem izlenmiştir: EPDK tarafından yayınlanan Sektör Raporu verileri (EPDK 2018a) ve AYEDAȘ'ın verileri ayrı ayrı değerlendirilmiştir. AYEDAŞ tarafından temin edilen ve yalnızca Ümraniye ilçesinde yer alan konutların elektrik tüketimini gösteren veriler doğrultusunda bu değer, 440.859 ton/yıl $\mathrm{CO}_{2}$ eşdeğeri olarak bulunmuştur. EPDK Sektör Raporu'nda yer alan veride ise İstanbul'un Avrupa ve Asya yakalarındaki tüketim değerleri verilmiş olup (EPDK 2018a), Ümraniye'deki tüketim değeri için nüfus üzerinden oranlama yapılmıştır. EPDK verisi üzerinden yapılan hesaplamalarda Ümraniye ilçesinde konutlarda elektrik tüketiminden kaynaklanan salınımın 243.531 ton/yıl $\mathrm{CO}_{2}$ eşdeğeri olduğu belirlenmiştir.

Mevcut çalışmada, EPDK verisi doğrultusunda İstanbul genelindeki elektrik tüketimi üzerinden hesaplamalar yapıldığında, olası bölgesel tüketim farlılıklarının ihmal edilmiş olacağı öngörülerek AYEDAŞ verisinin (440.859 ton/yıl $\mathrm{CO}_{2}$ eşdeğeri) kullanılmasına karar verilmiştir. Literatürde yer alan çalışmalarda, Erzurum ilinde (nüfusu yaklaşık 760.000 kişi) konutlarda elektrik tüketimi kaynaklı sera gazı salınımının 179.511 ton/yıl $\mathrm{CO}_{2}$ eşdeğerine karşılık geldiği hesaplanmıştır (Eren ve Erik 2015). TÜİK tarafından yayınlanan 2016 yılına ait kişi başı elektrik tüketim verilerinde, Türkiye genelinde bir kişinin yıllık elektrik tüketimi 2,897 kWh olarak tespit edilirken, bu değer İstanbul için 2,442 $\mathrm{kWh} / \mathrm{y} 1 \mathrm{l}$ ve Erzurum için 1,341 kWh/yıl olarak belirlenmiştir. Dolayısıyla yaklaşık benzer nüfuslara sahip Ümraniye ve Erzurum arasındaki elektrik tüketimi farklılığını, bu illerde yaşayanların alışkanlıkları ile ilişkilendirmek mümkündür (TÜİK 2017).

\subsubsection{Sanayi}

Sanayide Doğalgaz Tüketimi Kaynaklı $\mathrm{CO}_{2}$ Salınımı: Ekonomik çeşitlilik açısından zengin bir bölge olan Ümraniye'de sanayileşmenin daha çok küçük imalat sanayisi, konfeksiyon, yedek parça ve ağaç ürünleri üretimi üzerine olduğu görülmektedir (Temurçin ve Aldırmaz 2014). İlçede yalnızca bir büyük sanayi bölgesi (Dudullu OSB) yer almaktadır. Sanayide doğalgaz tüketimi ile ilgili veriler 01-15.07.2018 tarihinde İGDAŞ’tan temin edilmiştir. İGDAŞ’tan alınan veriler doğrultusunda 2017 yılında Ümraniye ilçesinde sanayi kaynaklı doğalgaz tüketimi $10.511 .876 \mathrm{Sm}^{3} / \mathrm{y}_{1} \mathrm{l}, \mathrm{buna}_{\mathrm{bağl}}$ sera gazı salınımı 20.363 ton/yıl $\mathrm{CO}_{2}$ eşdeğeri olarak tespit edilmiştir.

Sanayide tüketilen doğalgaz, konutlardaki (210.360.902 Sm³/yıl) ile kıyaslandığında çok daha düşük mertebelerde kalmaktadır. Türkiye genelinde doğalgaz tüketimi sektörlere göre incelendiğinde, 2017 y1lı için toplam tüketimin \%39'unun dönüşüm ve çevirimde (özellikle elektrik santrallerinde), \%25'inin konutlarda, \%28'inin sanayide ve \%6'sının hizmet sektöründe (ticarethane, resmi daire vb.) olduğu belirlenmiştir. Sanayide, doğalgazın yaygın tüketimi ise \%28 oranla OSB'lerde ve \%18 oranla kimya sektöründedir (Gazbir 2018). Ümraniye' deki durum incelendiğinde, ilçede sanayi faaliyetleri görülmekle birlikte, yalnızca bir adet OSB (Dudullu OSB) yer almakta, mevcut sektörlerin de doğalgaz tüketimi nispeten düşük oranlarda kalmaktadır. Sanayide ısınma amaçlı doğalgaz tüketimi yerine ise klima gibi elektrik tüketen sistemlerin kullanıldığg düşünülmektedir.

Sanayide Elektrik Tüketimi Kaynaklı CO Salınımı: Sanayide elektrik tüketiminden kaynaklı sera gazı salınımı, AYEDAŞ'tan temin edilen Ümraniye özelindeki veriler üzerinden hesaplanmıştır. 2017 yılında Ümraniye'deki sanayi kuruluşlarında $111.079 .775 \mathrm{kWh}$ elektrik tüketilmiş, bunun karşılığı olarak da 54.984 ton/yıl $\mathrm{CO}_{2}$ eşdeğeri emisyon oluştuğu belirlenmiştir.

İlçedeki konutlarla karşılaştırıldığında nispeten düşük olan bu değer, doğalgaz tüketimi ile benzerlik göstermektedir. $\mathrm{Bu}$ durum ilçedeki mevcut sanayinin büyük tesisler yerine, daha küçük imalat atölyelerinden oluşmasından kaynaklanmaktadır. Bununla beraber sanayi ve konutlardaki doğalgaz ve elektrik tüketimleri birlikte kıyaslandığında, aralarındaki dağılımın aynı oranda olmadığı, elektrik tüketim oranın sanayide daha yüksek olduğu görülmektedir. Bu durum sanayide 1sınma amaçlı elektrik tüketimini doğrular niteliktedir.

\subsubsection{Ticarethane ve Kurumlar}

Ticarethane ve Resmi Kurumlarda Doğalgaz Tüketimi Kaynaklı $\mathrm{CO}_{2}$ Salınımı: Ticarethane ve resmi kurumların doğalgaz tüketimi kaynaklı sera gazı salınımı İGDAŞ’tan temin edilen veriler doğrultusunda 119.917 ton $\mathrm{CO}_{2} / \mathrm{y}_{1}$ eşdeğeri olarak hesaplanmıştır. Bu salınımın \% 71'i ticarethanelerden gelmektedir. Elde edilen değer, literatürdeki çalışmalardan Pendik Belediyesi ile karşılaştırıldığında, Pendik ilçesinin $\mathrm{CO}_{2}$ salınımının 199.600 ton/yıl eşdeğeri olduğu gözlenmektedir (Pendik Belediyesi 2015). 
Ümraniye ve Pendik arasındaki bu fark, Pendik Belediyesi için yapılan hesaplamalarda, ticarethane ve sanayi kaynaklı salınımın birlikte değerlendirilmiş olmasından kaynaklanmaktadır. Ümraniye ilçesi için de bu şekilde hesaplama yapıldığında 140.280 ton $\mathrm{CO}_{2} /$ yıl değerine ulaşılmaktadır. Ümraniye ilçesindeki nüfus ve gelişim profillerinin Pendik’e benzediği dikkate alındığında, elde edilen emisyon değerinin anlamlı olduğu düşünülmektedir.

Ticarethane ve Kurumlarda Elektrik Tüketimi Kaynaklı CO Salınımı: Ticarethane ve kurumlardaki elektrik tüketimi verisi 15.08.2018 tarihinde AYEDAŞ’tan temin edilmiştir. Bu veriye göre 2017 y1lı elektrik tüketimi 1.170.135.277 kWh olup; buna bağlı olarak sera gazı salınımı 579.217 ton $\mathrm{CO}_{2} / \mathrm{y} 1$ l eşdeğeri bulunmuştur. Bu değer, İstanbul geneli için yapılan ve 6.652 .673 ton $\mathrm{CO}_{2} /$ yıl eşdeğeri salınımı gösteren çalışma ile karşılaştırılmış; Ümraniye'deki salınımım, İstanbul'daki toplam salınımın \%17'sini oluşturduğu gözlenmiştir. Bir diğer ifadeyle ticarethane ve kurumlardaki elektrik tüketimi, bütün salınım kaynakları arasında, ulaşımdan sonra gözlenen en büyük paya sahiptir (İBB 2015). İstanbul içinde farklı ilçelerdeki durum incelendiğinde, bu durumun ilçede yaşayan nüfustan bağımsız olarak Kadıköy ilçesinde (451.453 kişi) 294.142 ton $\mathrm{CO}_{2} /$ yıl (Kadıköy Belediyesi 2014); Pendik ilçesinde (698.260 kişi) 175.350 ton $\mathrm{CO}_{2} /$ yıl (Pendik Belediyesi 2015) olduğu gözlenmiştir. Bu durum ilçelerde yaşayanların genelde bulundukları bölge dışında çalışmakta olması ile açıklanabilmektedir.

\subsubsection{Sokak ve Sosyal Alanlarda Aydınlatma}

Ümraniye içerisindeki sokak ve sosyal alanların aydınlatılması ile ilgili elektrik tüketimi AYEDAŞ’tan 2017 yılı için $35.952 .033 \mathrm{kWh} /$ yıl olarak temin edilmiştir. Yapılan hesaplamalar sonucunda Ümraniye ilçesinde aydınlatma için elektrik tüketiminden kaynaklı sera gazı salınımı 17.796 ton/yıl $\mathrm{CO}_{2}$ eşdeğeri olarak bulunmuştur. EPDK 2017 yılı sektör raporuna göre Türkiye genelindeki toplam elektrik tüketiminin yaklaşı \%2'si, İstanbul genelindeki tüketimin ise \%1,13'ü aydınlatma amaçlı kullanılmaktadır (EPDK 2018a). Ümraniye için bu oran \%1,6 olup, elde edilen bu sonucun anlamlı olduğu düşünülmektedir.

\subsubsection{Ulaşım}

Ulaşımdan kaynaklanan sera gazı emisyonları; taşıtın özelliğine, yakıtın cinsine, trafik durumuna ve araziye bağlı olarak değişebilmektedir. Mevcut çalışmada ulaşımdan kaynaklı $\mathrm{CO}_{2}$ salınımının belirlenmesinde araçların sayıları, kullandıkları yakıtların cinsleri, yakıt tüketim miktarları ve yakıtın karbon içeriği dikkate alınmıştır. Hesaplamalarda mümkün olduğunca, daha detaylı yaklaşım olan, IEAP Protokolündeki ikinci yaklaşım (Tier 2) kullanılmıştır (ICLEI 2009). Yakıt tüketim verileri, 2017 yılına ait EPDK Yıllık Petrol Piyasası Raporu'nda sunulan satış istatistiklerinden alınmış (EPDK 2018b), emisyon faktörü belirlenmesinde ise Ulusal Sera Gazı Envateri Raporu Tablo1. A(b) (TÜIKK 2018c) ile Sera Gazı Emisyonlarının İzlenmesi ve Raporlanması Hakkında Tebliğ'in Ek-5'inde (22.07.2014 tarihli ve 29068 sayılı) yer alan değerler esas alınmıştır. Ulaşım kaynaklı sera gazı salınımı 321.027 ton $\mathrm{CO}_{2} / \mathrm{y}_{1}$ olarak hesaplanmış olup, elde edilen sonuçlar Tablo 4'te özetlenmiştir.

Tablo 4'ten görüldüğü üzere ulaşım kaynaklı toplam salınımda özel araçların etkisi \%50 oranında, toplu taşımanın etkisi \%12 oranında ve ticari araçların etkisi ise \%38 oranındadır. Tüm araçlar göz önüne alınarak kullanılan yakıta göre en yüksek emisyonun \%78 oranla motorinden kaynaklandığı belirlenmiştir. Bu durum toplu taşıma araçları ve ticari araçlarda daha çok motorinin kullanılmasının yanı sıra özel araçlarda da motorin kullanımının nipeten yüksek olması ile ilgilidir. Benzer şekilde Ümraniye ilçesinin yer aldığı İstanbul ili geneli için karayolu ile ulaşım ve taşımacılıktan kaynaklı salımlarda motorin kullanımı kaynaklı emisyonun \%80 olduğu hesaplanmıştır (İBB 2015).

Tablo 4: Ümraniye ilçesinde ulaşımdan kaynaklanan $\mathrm{CO}_{2}$ salınımlarının araç tiplerine göre dağılımı

\begin{tabular}{|c|c|c|c|}
\hline \multicolumn{2}{|l|}{ Araç Tipi } & Yakıt Tipi & $\begin{array}{c}\text { Karbon Ayak izi (ton/yıl } \\
\left.\text { essdeğer } \mathrm{CO}_{2}\right)\end{array}$ \\
\hline \multirow[t]{4}{*}{ Özel Araç } & \multirow[t]{3}{*}{ Otomobil } & Benzin & 45.472 \\
\hline & & Motorin & 84.957 \\
\hline & & LPG & 23.332 \\
\hline & Motosiklet & Motorin & 6.984 \\
\hline \multirow[t]{3}{*}{ Toplu Taşıma } & Minibüs & Motorin & 706 \\
\hline & Otobüs & Motorin & 31.867 \\
\hline & Raylı Sistem & Elektrik & 7.330 \\
\hline \multirow[t]{3}{*}{ Ticari Araç } & Kamyon & Motorin & 16.036 \\
\hline & Kamyonet & Motorin & 74.799 \\
\hline & Ticari Minibüs & Motorin & 29.545 \\
\hline TOPLAM & & & 321.027 \\
\hline
\end{tabular}




\subsubsection{Belediyenin Kendi Faaliyetleri Kaynaklı $\mathrm{CO}_{2}$ Salınımı}

Ümraniye Belediyesinin ana hizmet binası dışında 39 adet sosyal ve kültürel amaçlı hizmet binaları yer almaktadır. Bunlar kültür merkezi, bilgi evi, spor salonu ve sosyal tesis olarak sınıflanmaktadır. Belediyeye ait hizmet binaları özelinde elektrik ve doğalgaz tüketimi ile kullanılan araçlara bağlı sera gazı oluşumu hesaplanarak, Tablo 5'te sunulmuştur. Tablodan görüldüğü üzere belediyenin kendi hizmetleri kaynaklı karbon ayak izi 53.046 ton/yıl eşdeğer $\mathrm{CO}_{2}$ olup, bunun önemli bir kısmı (\%71) benzinli araç kullanımından gelmektedir.

Tablo 5: Belediyenin kendi faaliyetleri kapsamında oluşan karbon ayak izi

\begin{tabular}{|l|lr|}
\hline \multicolumn{2}{|l|}{ Emisyon Kaynağı } & Ayak izi (ton/yıl eşdeğer CO $\mathbf{C O}_{2}$ \\
\hline Elektrik Tüketimi & 3.081 \\
\hline Doğalgaz Tüketimi & 4.386 \\
\hline Ulaşım & & 36.008 \\
\hline & Benzin & 6.919 \\
\hline & Motorin & 53.046 \\
\hline Toplam & & \\
\hline
\end{tabular}

Yukarıdaki başlıklarda sunulan, ilçedeki ısınma ve elektrik tüketimi ile ilçedeki faaliyetler kaynaklı karbon ayak izi sonuçları Tablo 6'da özetlenmektedir. Elde edilen sonuçlar incelendiğinde hesaplanan karbon ayak izinin önemli bir kısmı konutlardaki doğalgaz ve kömür tüketiminden (\%42) kaynaklanmakta, ardından ticarethane ve resmi kuruluşlar (\%34) ile ulaşım faaliyetleri (\%16) sıralanmaktadır. Belediye hizmetleri kaynaklı emisyon oluşumu ise \%3 ile düşük mertebelerde kalmaktadır.

Tablo 6: Ümraniye ilçesindeki faaliyetler kaynaklı karbon ayak izi oluşumu

\begin{tabular}{|c|c|c|c|c|}
\hline \multirow{2}{*}{ Faaliyet } & \multicolumn{4}{|c|}{ Karbon Ayak İzi (ton/yıl eşdeğer $\mathrm{CO}_{2}$ ) } \\
\hline & $\begin{array}{l}\text { Doğalgaz/Kömür } \\
\text { Tüketimi }\end{array}$ & Elektrik Tüketimi & Yakıt Tüketimi & Toplam \\
\hline Konut & 420.340 & 440.859 & & 861.199 \\
\hline Sanayi & 20.363 & 54.984 & & 75.347 \\
\hline $\begin{array}{l}\text { Ticarethane ve Resmi } \\
\text { Kurumlar }\end{array}$ & 119.917 & 579.217 & & 699.134 \\
\hline Ulaşım & & & 321.027 & 321.027 \\
\hline Aydinlatma & & 17.796 & & 17.796 \\
\hline $\begin{array}{ll}\text { Belediyenin } & \text { Kendi } \\
\text { Faaliyetleri } & \end{array}$ & 4.386 & 3.081 & 42.927 & 53.046 \\
\hline Toplam & & & & 2.027 .549 \\
\hline
\end{tabular}

\subsection{Genel Değerlendirme}

\subsection{1. Ümraniye İlçesinde Doğalgaz, Elektrik ve Yakıt Tüketimlerinin Dağılımı}

Ümraniye'deki sera gazı salınımında etkin olan başlıca faktörlerden doğalgaz ve elektrik tüketiminin kaynaklara göre dağılımı ile araçların yakıt tüketimlerine göre dağılımları Şekil 1'de sunulmaktadır. Ümraniye ilçesindeki doğalgaz tüketimi incelendiğinde, konutlarda 1sınma amaçlı tüketimin \%74 oranla başı çektiği, arkasından \%22 oranla ticarethane ve resmi kurumların geldiği gözlenmektedir. Elektrik tüketimi ile ilgili dağılım incelendiğinde, ticarethane (\%53) ve konutlarda (\%40) kullanımın baskın olduğu gözlenmektedir (Şekil 1). Doğalgaz ve elektrik tüketiminin, kaynaklara göre dağılımınları arasındaki bu farkın, ticarethane ve resmi kurumlarda ısınmanın doğalgaz yerine elektrikle (klima ve 1sıtma gibi cihazların kullanımı) sağlanmasıyla ilişkilendirilmektedir. Ümraniye ilçesi için elde edilen sonuçlar, İstanbul geneli ile karşılaştırıldığında, İstanbul'da kullanılan elektriğin dağılımında konutların \%46, ticari ve resmi kurumların \%28, sanayinin ise $\% 26$ oranında pay sahibi olduğu görülmektedir. Doğalgaz tüketimi içinse bu dağılım; konutlarda \%66, ticari ve resmi kurumlarda \%21, sanayide \%13 olarak tespit edilmiştir (İBB 2015). Ümraniye ilçesi için elde edilen sonuçlar, İstanbul geneli ile kıyaslandığında anlamlı görünmektedir.

Ümraniye ilçesine kayıtlı araç türlerinin yakıtlarına göre tüketim değerleri incelendiğinde en fazla motorinin tüketildği (\%78), arkasından benzin (\%15) ve LPG'nin (\%7) geldiği görülmektedir (Şekil 1-c). EPDK Sektör Raporları'nda İstanbul genelinde satılan yakıtın \%83'ünün motorin, \%11'inin benzin ve \%6'sının LPG olduğu belirlenmiştir (EPDK 2018b). 
Bu değerlendirmenin, EPDK Sektör Raporları'nda İstanbul ili için verilen genel değerlendirme ile uyumlu olduğu görülmektedir.

Ümraniye ilçesinde kaynaklarına göre emisyonlar ve toplam içindeki payları Tablo 7'de sunulmaktadır. Tablodaki sera gazı salınımına en büyük olumsuz etkiye sebep olan kaynaklar dikkate alınarak, bu kaynaklara gelecek çalışmalarda azaltım stratejileri açısından öncelikle yer verilmesi önemlidir. Tablo 7'den görüldüğü üzere Ümraniye ilçesi için toplam sera gazı salınımının \%54'nün elektrik tüketiminden, \%28'inin doğalgaz (ile kömür) tüketiminden ve \%18'inin ulaşımdan (belediye araçları dahil) kaynaklandığı belirlenmiştir. Sera gazı salınımında elektrik kullanımının belirgin olarak önemli paya sahip olduğu benzer çalışmalarda da tespit edilmiştir.

Buna örnek olmak üzere bu dağılım İstanbul genelinde \%38 elektrik, \%21 doğalgaz ve \%28 ulaşım (İBB 2015); İzmir'de \%38 elektrik, \%28 doğalgaz ve \%19 ulaşım (İzmir Büyükşehir Belediyesi 2016); Bursa'da \%39 elektrik, \%24 doğalgaz ve \%19 ulaşım (Bursa Büyükșehir Belediyesi 2015) olarak bulunmuştur (Tablo 7'de Ümraniye ilçesi ve İstanbul geneli için emisyon kaynakları karşılaştırılmaktadır). Söz konusu illerde sıralamanın benzer ilerlemesi ile birlikte bölgeler arasındaki oranların değişiminde elektrik çevrim ve üretiminin yapılması, sanayinin sayı ve sektörlerine göre dağılımı ve bölgedeki tüketim alışkanlıkları belirleyici olmaktadır. Diğer taraftan bölgelerdeki kaçak kullanımların da bu dağılıma etki ettiği düşünülmektedir. Elektrikteki 2017 yılı kayıp oranları İstanbul Anadolu yakası geneli için 15.08.2018 tarihinde AYEDAŞ tarafından \%6 olarak beyan edilirken EPDK Raporunda Güneydoğu Anadolu bölgesi için yaklaşık \%65 olarak tespit edilmektedir (EPDK 2018a).

Ümraniye ileçesi için elde edilen sonuçlar doğrudan emisyon (kapsam 1) ve dolaylı emisyon (kapsam 2) olmaları üzerinden incelendiğinde sırasıyla \%46 ve \%54 olmak üzere benzer oranlarda dağıldığını söylemek mümkündür (Tablo $8)$.

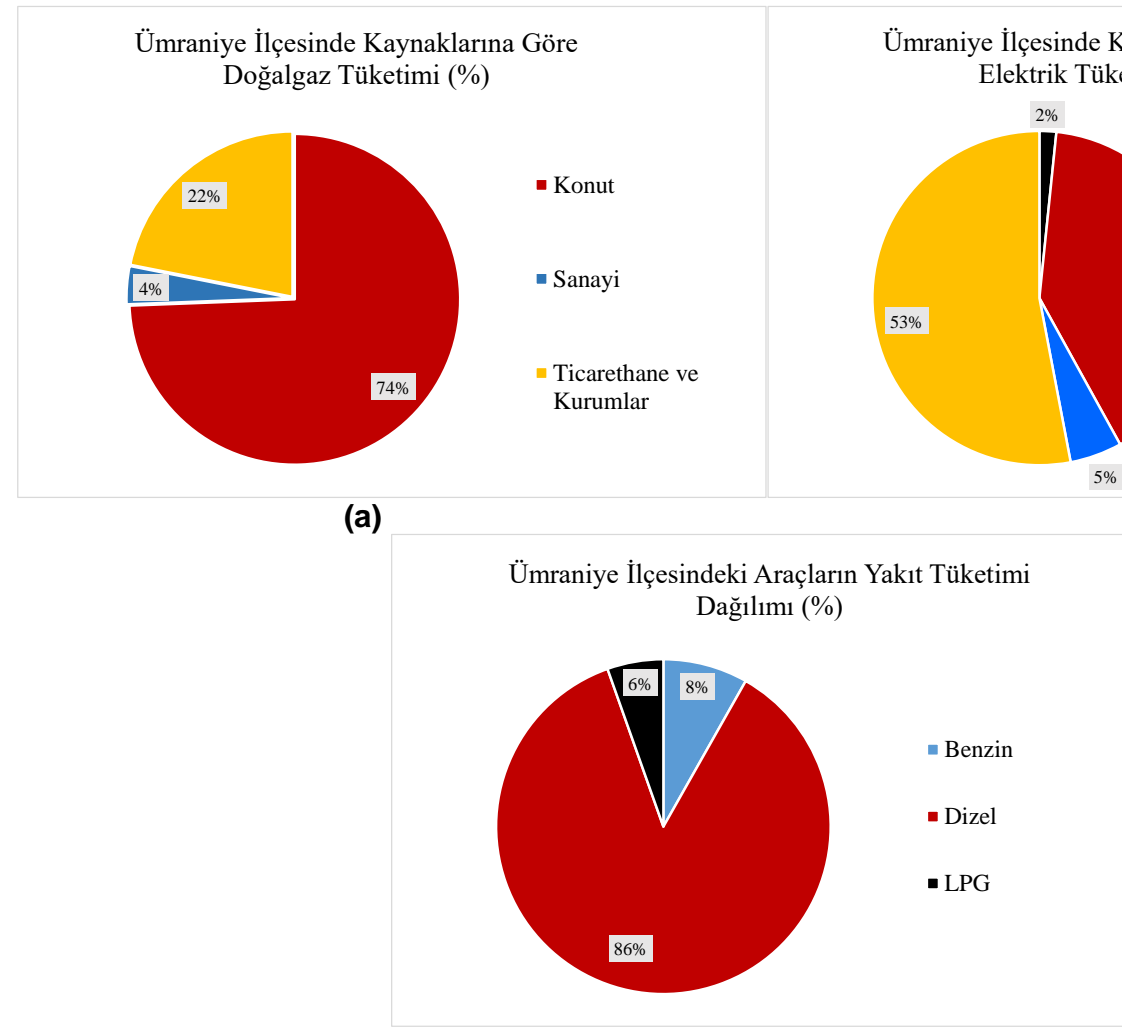

(c)

Şekil 1: Ümraniye ilçesindeki tüketimlerin kaynaklarına göre dağıımı a) doğalgaz, b) elektrik, c) yakıt düketimi 
Tablo 7: Ümraniye ilçesi ve İstanbul ili geneli için emisyon kaynaklarının dağılımı

\begin{tabular}{|c|c|c|c|c|c|}
\hline \multirow{2}{*}{\multicolumn{2}{|c|}{ Emisyon Kaynağı }} & \multicolumn{2}{|c|}{ Ümraniye (2017) } & \multicolumn{2}{|c|}{ İstanbul (2015)* } \\
\hline & & \multirow{2}{*}{$\begin{array}{r}\begin{array}{c}\text { Ayak izi (ton/yıl } \\
\text { eşdeğer } \mathbf{C O}_{2} \text { ) }\end{array} \\
407.507\end{array}$} & \multirow{2}{*}{$\begin{array}{l}\begin{array}{c}\text { Toplam İçindeki } \\
\text { Payı (\%) }\end{array} \\
20\end{array}$} & \multirow{2}{*}{$\begin{array}{c}\begin{array}{c}\text { Ayak izi } \\
\text { (ton/yll } \\
\text { eşdeğer COO }\end{array} \\
7.680 .593\end{array}$} & \multirow{2}{*}{$\begin{array}{c}\begin{array}{c}\text { Toplam } \\
\text { İçindeki Payı } \\
(\%)\end{array} \\
16\end{array}$} \\
\hline \multirow[b]{2}{*}{ Konut } & Doğalgaz & & & & \\
\hline & Elektrik & 440.859 & 22 & 6.652 .673 & 14 \\
\hline \multirow{2}{*}{$\begin{array}{l}\text { Ticarethane ve } \\
\text { Kurumlar }\end{array}$} & Doğalgaz & 119.917 & 6 & 1.495 .840 & 3 \\
\hline & Elektrik & 579.217 & 29 & 7.939 .816 & 17 \\
\hline \multirow{2}{*}{ Sanayi } & Doğalgaz & 2.036 & 1 & 2.481 .486 & 5 \\
\hline & Elektrik & 54.984 & 3 & 3.508 .344 & 7 \\
\hline Ulaşım & Motoin, Benzin, LPG & 321.026 & 16 & 10.670 .516 & 23 \\
\hline
\end{tabular}

* BBB Sera Gazı Envanteri Raporunda (2015) İstanbul için havalimanları ve elektrik üretim tesisleri dikkate alınmamıştır.

Tablo 8: Ümraniye ilçesinde kaynaklarına göre emisyonlar ve toplam içindeki payları

\begin{tabular}{|c|c|c|c|c|}
\hline \multirow{2}{*}{$\begin{array}{ll} & \text { Kapsam } \\
\text { Konut } & \end{array}$} & \multicolumn{2}{|c|}{ Emisyon Kaynağı } & \multirow[t]{2}{*}{ Ayak izi (ton/yıl eşdeğer $\mathrm{CO}_{2}$ ) } & \multirow[t]{2}{*}{ Toplam İçindeki Payı (\%) } \\
\hline & & & & \\
\hline Kapsam 1 & Doğrudan Emisyon & Doğalgaz & 407.507 & 20,1 \\
\hline Kapsam 1 & Doğrudan Emisyon & Kömür & 12.834 & 0,6 \\
\hline Kapsam 2 & Enerji Dolaylı Emisyon & Elektrik & 440.859 & 21,7 \\
\hline \multicolumn{5}{|l|}{ Sanayi } \\
\hline Kapsam 1 & Doğrudan Emisyon & Doğalgaz & 20.363 & 1,0 \\
\hline Kapsam 2 & Enerji Dolaylı Emisyon & Elektrik & 54.984 & 2,7 \\
\hline \multicolumn{5}{|c|}{ Ticarethane ve Kurumlar } \\
\hline Kapsam 1 & Doğrudan Emisyon & Doğalgaz & 119.917 & 5,9 \\
\hline Kapsam 2 & Enerji Dolaylı Emisyon & Elektrik & 579.217 & 28,6 \\
\hline \multicolumn{5}{|l|}{ Aydınlatma } \\
\hline Kapsam 2 & Enerji Dolaylı Emisyon & Elektrik & 17.796 & 0,9 \\
\hline \multicolumn{5}{|l|}{ Ulaşım } \\
\hline Kapsam 1 & Doğrudan Emisyon & Benzin & 45.471 & 2,2 \\
\hline Kapsam 1 & Doğrudan Emisyon & Motorin & 244.893 & 12,1 \\
\hline Kapsam 1 & Doğrudan Emisyon & LPG & 23.332 & 1,2 \\
\hline Kapsam 2 & Enerji Dolaylı Emisyon & Elektrik & 7.330 & 0,4 \\
\hline \multicolumn{5}{|l|}{ Belediye } \\
\hline Kapsam 1 & Doğrudan Emisyon & Doğalgaz & 4.386 & 0,2 \\
\hline Kapsam 2 & Enerji Dolaylı Emisyon & Elektrik & 3.081 & 0,2 \\
\hline Kapsam 1 & Doğrudan Emisyon & Benzin & 37.522 & 1,9 \\
\hline Kapsam 1 & Doğrudan Emisyon & Motorin & 8.057 & 0,4 \\
\hline
\end{tabular}

\subsubsection{Sera Gazı Salınımının Kişi Başı Üzerinden Değerlendirilmesi}

Ümraniye ilçesindeki sera gaz salınımı kişi başı üzerinden değerlendirildiğinde, bu değerin 2017 yılı için 2,55 ton $\mathrm{CO}_{2} /$ kişi olduğu belirlenmektedir. Bu değer TÜiK tarafindan Türkiye'nin 2017 y1lı için belirlenmiş olan 6,60 ton/kişi değerinin çok altındadır (TÜIK 2018d). TÜIK tarafından hazırlanmış Türkiye Sera Gazı Envanteri Raporu'nda tespit edilen toplam $\mathrm{CO}_{2}$ eşdeğer emisyonun en önemli kısmının $(\% 72,8)$ "enerji kaynaklı" emisyonlar olduğu belirtilmiştir. Bunu sırasıyla endüstriyel işlemler ve ürün kullanımı $(\% 12,6)$, tarımsal faaliyetler $(\% 11,4)$ ve atık bertarafı $(\% 3,3)$ izlemiştir. Enerji kaynaklı emisyonlar başlı̆̆ altında en önemli payları ise \%36 ile enerji üretimi (çevrim ve enerji sektörü adı altında) ve \%20 ile ulaştırma oluşturmaktadır (TÜIK 2017; TÜIK 2018d). Ümraniye ilçesinde başta enerji üretimi olmak üzere, tarımsal faaliyetlerin ve atık bertarafının ilçe sınırlarında yer almayışı, ilçedeki kişi başı emisyon değerinin (2,55 ton/kişi), Türkiye geneline (6,60 ton/kişi) göre düşük olması ile sonuçlanmaktadır. Diğer taraftan, Türkiye genelindeki kişi başı $\mathrm{CO}_{2}$ eşdeğer emisyonunun yıllara göre değişimi incelendiğinde, bu değerin 1990 'da 3,88 ton/kişi, yakın zamanlarda yapılan 2015 ve 2016 yıllarında sırasıyla 6,07 ve 6,30 ton/kişi olduğu, en son değerlendirmenin yapıldığı 2017 yılında ise 6,60 ton/kişi olduğu belirlenmiştir (TÜIK 2018d). Bu değerin AB üye ülkeleri ortalama değeri olan 8,75 ton/kişi altında olmasına karşın, Türkiye'de yıllar içinde hızlı bir artış olduğu görülmektedir. Bu hızlı artış, ekonomik ve endüstriyel kalkınmaya paralel olarak enerji tüketimindeki ivmelenme ile ilişkilendirilmektedir (ÇŞB 2018).

Benzer bir değerlendirme İstanbul ili için yapıldığında, 2015 yılı toplam sera gazı salınımı 47,7 milyon ton $\mathrm{CO}_{2}$ eşdeğeri, kişi başına düşen emisyon ise 3,23 ton/yıl olarak belirlenmiştir (IBBB 2015). 2015 yllındaki 47,7 milyon ton $\mathrm{CO}_{2}$ eşdeğeri salınımı ile İstanbul'un, Türkiye'nin toplam sera gazı salınımındaki \%11'lik paya sahip olduğunu gözlenmektedir. 
2015 yılı için İstanbul'daki emisyonların \%30’u konutlardan (elektrik tüketimi \%14, doğalgaz tüketimi \%16), \%23’ü karayolu ile ulaşımdan, \%17'si ticari ve kurumsal binalardan (elektrik tüketimi) ve \%12'si sanayiden (elektrik tüketimi \%7, doğalgaz tüketimi \%5) kaynaklanmıştır (İBB 2015). Bu sonuçlardan görüldüğü üzere İstanbul'da kişi başına düşen sera gazı salınımı (3,23 ton/kişi, 2015) Türkiye geneline (6,07 ton/kişi, 2015) göre düşüktür. Bunun sebebi, özellikle enerji üretimine yönelik faaliyetlerin İstanbul'da yer almamasıdır (EPDK 2018a).

Mevcut çalışmaya benzer nitelikte sera gazı salınımının belirlendiği Pendik ilçesinde, 2014 yılındaki kişi başı emisyon 10,69 ton/kişi olarak belirlenmiştir (Pendik Belediyesi 2015). Ümraniye'nin dişında, Türkiye geneli ve İstanbul ili ile karşılaştırıldığında bile çok yüksek olan bu değerin, Pendik’te yer alan Sabiha Gökçen Havalimanı'ndan kaynaklandığı gözlenmektedir. Sabiha Gökçen Havalimanın Pendik ilçesindeki sera gazı salınımına etkisi \%80 oranındadır (Pendik Belediyesi 2015). Aynı değerlendirme, havalimanının var olmadığı varsayımı ile yapıldığında, kişi başı salınımın yaklaşık 2,00 ton/yıl civarında olduğu belirlenmektedir. Pendik ilçesi için hesaplanan değerlerin zamanla yükselmesi (2012'de 3,57 ton/kişi, 2013 'te 6,23 ton/kişi ve 2014 'te 10,69 ton/kişi) uçuşların artmasına bağlanmıştır.

\section{Sonuç ve Öneriler}

Mevcut çalışmada 2017 yılı içerisinde Ümraniye ilçesinde konut, ticarethane ve resmi kurumlar ile sanayide tüketilen elektrik ve doğalgazın yanı sıra ulaşımdan kaynaklanan sera gazı salınımı belirlenmiştir. Elde edilen sonuçlar aşağıda özetlenmektedir:

- Ümraniye'de toplam sera gazı salınımı 2.027.549 ton/yıl $\mathrm{CO}_{2}$ eşdeğeri olarak belirlenmiş olup, kişi başına düşen emisyon 2,55 ton $\mathrm{CO}_{2}$ /kişi olarak hesaplanmıştır.

- İlçedeki sera gazı salınımının \%43'ü konutlardan (\%21'i doğalgaz ve kömür, \%22'si elektrik tüketimi), \%35'i ticarethane ve resmi kurumlardan (\%6'sı doğalgaz, \%29'u elektrik tüketimi), \%16'sı ulaşımdan ve kalanı sanayi ve belediye hizmetlerinden kaynaklanmaktadır.

- Emisyon kaynaklarına göre değerlendirme yapıldığında elektrik tüketimi \%54, doğalgaz tüketimi (ile kömür) \%28 ve yakıt tüketimi $\% 16$ oranda etkilidir.

- IEAP'de sera gazı salınımları kategorizasyonunda ele alınan kapsam 1 ve kapsam 2'ye göre, mevcut salınımların \%46'sı doğrudan emsiyon (kapsam 1), \%54'ü dolaylı emisyon (kapsam 2) niteliğindedir.

- Ulaşım kaynaklı emisyonda özel araçların etkisi \%50 iken; toplu taşımanın etkisi \%12'dir. Kullanılan yakıtlardan emisyona en çok etki edenin, tüketime bağlı olarak, motorin (\%78) olduğu belirlenmiştir.

Ümraniye Belediyesi özelinde yapılan bu çalışmada, yerel yönetimlerin karbon ayak izinin hesaplanması için bir yol haritası oluşturulması hedeflenmiştir. Çalışmada sunulan yaklaşımla, gerek İstanbul içerisindeki, gerek Türkiye genelindeki diğer belediyelerin sera gazı salınımlarındaki mevcut durumun tespitinin yapılması mümkündür. Ancak karbon ayak izinin hesabının kullanılan parametreler ve verilerin detaylandırılmasına bağlı olarak gün geçtikçe geliştirilir nitelikte olduğu, bu çalışma ile kompleks bir hesap yöntemi yerine daha az zaman ve veri kullanılarak daha basit ve yaygın bir metodolojinin ortaya konmuş olduğunu belirtmek önemlidir. İlçelerdeki mevcut karbon ayak izinin belirlenmesinden sonraki aşama belediyelerin sera gazı azaltım hedeflerini ortaya koyarak, eylem planları hazırlamasıdır. $\mathrm{Bu}$ çalışma ile eylem planlarında karar vericiler için yol gösterici olan "Hangi kaynaktan, ne miktarda kirletici gelmektedir, ne oranda iyileştirme yapılması gerekir?” sorularına cevap bulunabileceği düşünülmektedir. Bu duruma örnek olmak üzere Ümraniye ilçesindeki sera gazı salınımında başta elektrik tüketiminin (\%54) olumsuz etkisi olduğu belirlenmiştir. Elektrik tüketiminde ticarethane ve resmi kurumların önemli paya sahip olduğu görülmektedir (\%50). Ticarethane ve resmi kurumlardaki tüketim değerlerinin azaltılmasına ilişkin "Binalarda Enerji Performansı Yönetmeliği (05.12.2008 tarihli, 27075 sayıl1)" ve "Enerji Verimliliği Strateji Belgesi (25.02.2012 tarihli, 28215 sayıl1)" dikkate alınarak yalıtım ve izolasyon önlemlerinin alınması gerekmektedir. Diğer taraftan özellikle ticarethane ve resmi kurumlar için 1sınmada doğalgaz ve elektrik kullanımları karşılaştırıldığında, elektriğin tercih edildiği ancak doğalgaz kullanımının daha düşük karbon ayak izine sebep olacağı belirlenmektedir. Ümraniye ilçesindeki sera gazı oluşumunda önemli etkisi olan (\%43) konutlarla ilgili olarak "Binalarda Enerji Performansı Yönetmeliği” gereği, bütün binalarda Enerji Kimlik Belgesi'nin alınması ve yönetmelikte yer alan kriter değerlerin sağlanması gerekmektedir. Bu durumda tespit edilen binalarda yalıtım ve izolasyon önlemlerinin alınması gerekmektedir. Ulaşımdan kaynaklanan emisyonlarda özel araç kullanımı en yüksek emisyon kaynağıdır (\%50). Ulaşım kaynaklı emisyonların azaltımında toplu taşımanın, özellikle de raylı sistem kullanımının arttırılması önerilmektedir. Belediyenin kendine ait olan hizmet ve atık toplama araçlarının ise daha düşük emisyonlu araçlarla yenilenmesi önemlidir. Bu önlemlerin dışında tüketim alışkanlıklarının değiştirilmesi ve enerjinin verimli kullanılması başta olmak üzere toplum bilincinin arttılmasına yönelik çalışmaların pek çok önemli sonuç yaratacağ 1 düşünülmektedir.

Belediyeler tarafından karbon ayak izinin belirlenmesi çalışmaları sırasında yaşanabilecek güçlüklerin başında veri temini gelmektedir. İhtiyaç duyulan verilerin pek çok farklı kurumdan temin edilmesi gerekmekte ancak veri istenen ölçeklerde olamayabilmekte veya temininde güçlükler yaşanabilmektedir. Diğer taraftan karbon emisyonlarının hesaplanmasında GHG protokolünde yer alan sınıflandırmalardan Kapsam 1 ve Kapsam 2 için veri toplama ve hesaplama bahsedildiği şekilde nispeten mümkün olabilirken, Kapsam 3 için hesaplama genelde yapılamamaktadır. 
Bu hesabın yapılabilmesi için gerekli veri tabanının oluşturulması önem taşımaktadır. Ayrıca mevcut çalışma kapsamında oluşan sera gazlarının tutulmasında önemli rol oynayan yutak alanları sıralanan sebeplerden çalışmaya dahil edilememiş olup, diğer çalışmalarda dikkate alınması önerilmektedir.

\section{Teşekkür}

Bu çalışma, Marmara Üniversitesi Siyasal Bilgiler Fakültesi Siyaset Bilimi ve Kamu Yönetimi Bölümü ile Kent Sorunları ve Yerel Yönetimler Araştırma Merkezi (KEYEM)'nin ortak çalışması olarak gerçekleştirilmiştir. Çalışmadaki verilerin temininde bizlere destek olan Ümraniye Belediyesi, AYEDAŞ, İGDAŞ, İETT Enerji ve Çevre Yönetim Müdürlüğü ve TUHIM'e teşekkürlerimizi sunarız.

\section{Kaynaklar}

Argun M. E., Ergüç R., Sarı Y., (2019), Konya/Selçuklu ilçesi karbon ayak izinin belirlenmesi, Selçuk Üniversitesi Mühendislik, Bilim ve Teknoloji Dergisi, 7(2), 287-297.

Atabey T., (2013), Karbon ayak izinin hesaplanmast: Diyarbakır örneği, Yüksek Lisans Tezi, Fırat Üniversitesi Fen Bilimleri Enstitüsü, Elazı̆̆.

Bursa Büyükşsehir Belediyesi, (2015), Bursa Büyükşehir Belediyesi Kurumsal ve Kentsel Karbon Ayak İzi Envanteri, http://www.skb.gov.tr/wp-content/uploads/2017/01/Bursa-Buyuksehir-Belediyesi-Kurumsal-Ve-Kentsel-Karbon-Ayak-IziEnvanteri.pdf, [Erişim 15 Mayıs 2019].

ÇŞB, (2018), Çevresel Göstergeler 2016, Çevre ve Şehircilik Bakanlığı, https://webdosya.csb.gov.tr/db/ced/icerikler/gostergeler-201620180618144826.pdf, [Erişim 15 Mayıs 2019].

ÇŞB, (2019a), Birleşmiş Milletler İklim Değişikliği Çerçeve Sözleşmesi, https://iklim.csb.gov.tr/birlesmis-milletler-iklim-degisikligicerceve-sozlesmesi-i-4362, [Erişim 12 Temmuz 2019].

ÇŞB, (2019b), Kyoto Protokolü, https://iklim.csb.gov.tr/kyoto-protokolu-i-4363, [Erişim 12 Temmuz 2019].

Dulkadiroğlu H., (2018), Türkiye'de Elektrik Üretiminin Sera Gazı Emisyonları Açısından İncelenmesi, Ömer Halisdemir Üniversitesi Mühendislik Bilimleri Dergisi, 7(1), 67-74.

EPA, (2019), Overview of Greenhouse Gases, https://www.epa.gov/ghgemissions/overview-greenhouse-gases, [Erişim 12 Temmuz 2019].

EPDK, (2018a), Elektrik Piyasası Gelişim Raporu 2017, Enerji Piyasası Düzenleme Kurumu, Strateji Geliştirme Dairesi Başkanlığı, file:///C:/Users/HandeGursoy/Downloads/_PortalAdmin_Uploads_Content_FastAccess_447300fc51955.pdf, [Erişim 15 May1s 2019].

EPDK, (2018b), Petrol Piyasası Gelişim Raporu 2017, Enerji Piyasası Düzenleme Kurumu, Strateji Geliştirme Dairesi Başkanlığı, https://www.epdk.org.tr/Detay/Icerik/2-3603/2017-yili-sektor-raporlari-yayinlanmistir, [Erişim 15 May1s 2019].

Eren Z., Erik Z., (2015), Erzurum sera gaz envanteri, emisyon azaltım ve sürdürülebilir enerji eylem planı, Erzincan Üniversitesi Fen Bilimleri Enstitüsü Dergisi, 8(2), 259-271.

Gazbir, (2018), 2017 Yılı Doğal Gaz Dağıtım Sektörü Raporu, Türkiye Doğal Gaz Dağıtıcıları Birliği, https://www.gazbir.org.tr/ uploads/page/2018-Dogal-Gaz-Sektor-Raporu.pdf, [Erişim 15 Mayıs 2019].

Gürel A., Balta Y., (2011), İstanbul'un Göç Olayı ve Etnik Hayat Üzerine, Marmara Sosyal Araştırmalar Dergisi, 1, 1-15.

İBB, (2015), İstanbul Büyükşsehir Belediyesi, İstanbul İklim Değişikliği Eylem Planı Sera Gazı Envanteri, İstanbul Büyükșehir Belediyesi, https://www.iklim.istanbul/wp-content/uploads/Sera_Gaz\%C4\%B1_Envanter_Raporu.pdf, [Erişim 15 May1s 2019].

ICLEI, (2009), International Local Government Greenhouse Gas Emissions GHG Emissions Analysis Protocol (IEAP), Version 1.0, https://carbonn.org/fileadmin/user_upload/carbonn/Standards/IEAP_October2010_color.pdf, [Erişim 15 May1s 2019].

İETT, (2018), Karbon ayak izi hesaplama, http://www.iett.istanbul/files/karbon-hesabi/, [Erişim 15 Temmuz 2018].

IPCC, (2006), Intergovernmental Panel on Climate Change (2006) 2006 IPCC Guidelines for National Greenhouse Gas Inventories: Vol. 2: Energy (stationary, mobile, and fugitives), Vol. 3: Industry, IPCC, Geneva, İsviçre, https://www.ipccnggip.iges.or.jp/public/2006gl/index.html, [Erişim 15 Mayıs 2019].

IPCC, (2014), Climate Change 2014: Mitigation of Climate Change. Contribution of Working Group III to the Fifth Assessment Report of the Intergovernmental Panel on Climate Change, Cambridge University Press, Cambridge, United Kingdom and New York, NY, USA, https://www.ipcc.ch/site/assets/uploads/2018/02/ipcc_wg3_ar5_full.pdf, [Erişim 15 Mayıs 2019].

IPCC, (2018), Summary for Policymakers. In: Global warming of $1.5^{\circ} C$, Geneva, İsviçre, https://www.ipcc.ch/site/assets/uploads/sites/2/2019/05/SR15_SPM_version_report_LR.pdf, [Erişim 15 May1s 2019].

İzmir Büyükşehir Belediyesi, (2016), İzmir Sürdürülebilir Enerji Eylem Planı, https://skpo.izmir.bel.tr/Upload_Files/FckFiles/file/ izmir_surdurulebilir_eylem_plani_2017.pdf, [Erişim 15 Mayıs 2019].

Kadıköy Belediyesi, (2014), Kadıköy Belediyesi Sürdürülebilir Enerji Eylem Planı, https://anlat.kadikoy.bel.tr/kbpanel/Uploads/ Files/KadikoySEEP.pdf, [Erișim 15 Mayıs 2019].

Metro İstanbul, (2018), 2017 Yllı Faaliyet Raporu, Metro İstanbul Sanayi ve Ticaret Anonim Şirketi, https://www.metro.istanbul/ Content/assets/uploaded/2017\%20Faaliyet\%20Raporu.pdf, [Erişim 15 Mayıs 2019].

MFA, (2019), Paris Anlaşması, http://www.mfa.gov.tr/paris-anlasmasi.tr.mfa, [Erişim 12 Temmuz 2019].

NASA (2019), What is the greenhouse effect?, https://climate.nasa.gov/faq/19/what-is-the-greenhouse-effect/, [Erişim 12 Temmuz 2019].

Pendik Belediyesi, (2015), Pendik ilçesi karbon ayak izi çalışması, Pendik Belediyesi, Strateji Geliştirme Müdürlüğü, http://www.skb.gov.tr/wp-content/uploads/2017/01/Pendik-Ilcesi-Karbon-Ayak-Izi.pdf, [Erișim 15 Mayıs 2019]. 
REC, (2009), Uluslararası Yerel Yönetimler Sera Gazı Salımlarının Analizi Protokolü, Versiyon 1.0 (IEAP), Orta ve Doğu Avrupa için Bölgesel Çevre Merkezi (REC), Ankara, file:///C:/Users/HandeGursoy/Downloads/IEAP_Turkce_VF_Eylul2012.pdf, [Erişim 15 Mayis 2019].

Rosenzweig C., Solecki W.D., Hammer S.A., Mehrotra S., (2011), Climate change Change and Cities: First Assessment Report of the Urban Climate Change Research Network, Cambridge University Press, New York, USA, 286ss.

Temurçin K., Aldırmaz Y., (2014), The development and structure Structure of industry Industry in the district District of Ümraniye, Istanbul, Prace Komisji Geografii Przemysłu Polskiego Towarzystwa Geograficznego, 26, 207-233.

Turan R.B., Karaer F., (2019), Bursa Osmangazi belediyesi kurumsal karbon ayak izi hesabı ve iklim değişikliği uyum çalışmaları, İklim Değișikliği ve Çevre, 4(1), 17-24.

TÜBİTAK MAM, (2010), Havza Koruma Eylem Planlarının Hazırlanması Projesi, T.C. Orman ve Su İşleri Bakanlığı Projesi, Ankara.

TÜIK, (2017), 2016 Yılı Kişi Başına Toplam Elektrik Tüketimi Verisi, Türkiye İstatistik Kurumu, http://www.tuik.gov.tr/ PreTablo.do?alt_id=1029\#, [Erişim 15 Temmuz 2018].

TÜİK, (2018a), 2017 Yılı Adrese Dayalı Nüfus Kayıt Sistemi Sonuçları, Türkiye İstatistik Kurumu, https://biruni.tuik.gov.tr/ medas/?kn=95\&locale=tr, [Erişim 15 Temmuz 2018].

TÜİK, (2018b), İstatistiklerle Türkiye 2017, Turkey in Statistics 2017, Türkiye İstatistik Kurumu, Ankara.

TÜIK, (2018c), Türkiye Sera Gazı Envateri (1990-2016), Türkiye İstatistik Kurumu, Ankara.

TÜIK, (2018d), Sera Gazı Emisyon İstatistikleri, 2016, 13.04.2018 tarihli Haber Bülteni, http://www.tuik.gov.tr/ PreHaberBultenleri.do?id=27675, [Erişim 15 Temmuz 2018].

UN, (1992), United Nations Framework Convention on Climate Change, https://unfccc.int/resource/docs/convkp/conveng.pdf, [Erişim 31 Mart 2019].

UN, (2012), Doha Amendment to the Kyoto Protocol, https://unfccc.int/files/kyoto_protocol/application/pdf/kp_doha_amendment_ english.pdf, [Erişim 12 Temmuz 2019].

UN, (2015), Paris Agreement, https://unfccc.int/sites/default/files/english_paris_agreement.pdf, [Erişim 12 Temmuz 2019].

UN, (2019), Paris Agreement, https://treaties.un.org/Pages/ViewDetails.aspx?src=TREATY\&mtdsg_no=XXVII-7-d\&chapter=27\& clang=_en, [Erişim 12 Temmuz 2019].

URL-1, (2003), İklim Değişikliği Çerçeve Sözleşmesine Katılmamızın Uygun Bulunduğuna Dair Kanun, Resmi Gazete Tarih: 21/10/2003, Sayı: 25266, https://www.tbmm.gov.tr/kanunlar/k4990.html, [Erişim 15 Ocak 2019].

URL-2, (2009), Birleşmiş Milletler İklim Değişikliği Çerçeve Sözleşmesine Yönelik Kyoto Protokolüne Katılmamızın Uygun Bulunduğuna Dair Kanun, Resmi Gazete Tarih: 17/2/2009, Say1: 27144, https://www.tbmm.gov.tr/kanunlar/k5836.html, [Erişim 15 Ocak 2019].

URL-3, (2015), INDCs as Communicated by Parties, http://www4.unfccc.int/submissions/INDC/Published\%20Documents/Turkey/ 1/The_INDC of TURKEY v.15.19.30.pdf, [Erişim 31 Ocak 2019].

URL-4, (2018), Consumption Based GHG Emissions of C40 Cities, https://www.c40.org/researches/consumption-based-emissions, [Erişim15 Ocak 2019]

URL-5, (2020), Covenant Community, https://www.covenantofmayors.eu/about/covenant-community/signatories.html, [Erişim 25 Ocak 2020].

Ümraniye Belediyesi, (2019a), Ümraniye Belediyesi Taşınmaz Envanteri, https://www.umraniye.bel.tr/tr/main/pages/umraniyebelediyesi-tasinmaz-envanteri/131, [Erişim 15 Ocak 2019].

Ümraniye Belediyesi, (2019b), Ümraniye İlçesinin Mahalle Bazında Nüfusları ve Yüzölçümü, https://www.umraniye.bel.tr/tr/main/pages/umraniye-ilcesinin-mahalle-bazinda-nufuslari-/132, [Erişim 15 Ocak 2019].

Ümraniye Belediyesi, (2019c), Ümraniye Belediyesi 2018 Yllı Faaliyet Raporu, Ümraniye Belediyesi, https://mobil.umraniye.bel.tr/ userfiles/files/FaaliyetRaporlari/FaaliyetRaporu2018\%20.pdf, [Erişim 15 Ocak 2019]. 